\title{
Northern Cheyenne Reservation Coal Bed Natural Resource Assessment and Analysis of Produced Water Disposal Options
}

Shaochange Wo

David L. Lopez

Jason Whiteman Sr.

July 2004

Idaho National Engineering and Environmental Laboratory Bechtel BWXT Idaho, LLC 


\title{
NORTHERN CHEYENNE RESERVATION COAL BED NATURAL RESOURCE ASSESSMENT AND ANALYSIS OF PRODUCED WATER DISPOSAL OPTIONS
}

\author{
Final Report \\ By \\ Shaochang Wo \\ David A. Lopez \\ Jason Whiteman Sr.
}

July 2004

Work Performed Under Contract No. DE-AC07-99ID13727

\author{
Prepared for \\ U.S. Department of Energy \\ National Petroleum Technology Office \\ Native American Initiative \\ Jesse Garcia, Project Manager \\ Williams Center Tower 1 \\ 1 West Third Street, Suite 1400, Tulsa, OK 74103 \\ Prepared by \\ Idaho National Engineering and Environmental Laboratory \\ P.O. Box 1625, 2525 North Fremont Ave., Idaho Falls, ID 83415 \\ Montana Bureau of Mines and Geology \\ 1300 N. $27^{\text {th }}$ Street, Billings, MT 59101 \\ Natural Resources Department, Northern Cheyenne Tribe \\ P.O. Box 128, Lame Deer, MT 59043
}




\section{DISCLAIMER}

This report was prepared as an account of work sponsored by an agency of the United States Government. Neither the United States Government nor any agency thereof, nor any of their employees, makes any warranty, express or implied, or assumes any legal liability or responsibility for the accuracy, completeness or usefulness of any information, apparatus, product, or process disclosed, or represents that its use would not infringe privately owned rights. Reference herein to any specific commercial product, process, or service by trade name, trademark, manufacturer, or otherwise does not necessarily constitute or imply its endorsement, recommendation, or favoring by the United States Government or any agency thereof. The views and opinions of authors expressed herein do not necessarily state or reflect those of the United States Government or any agency thereof. 


\section{Acknowledgments}

This project was supported by the U.S. Department of Energy (DOE) through the Native American Initiative of the National Petroleum Technology Office under contract DE-AC07-99ID13727. Matching funds were granted by the Montana Bureau of Mines and Geology (MBMG) in supporting the work of geologic study and mapping conducted at MBMG. We thank Mike Cannon of USGS in Helena, Montana, for providing the water chemistry data sampled from the USGS wells on the Northern Cheyenne Indian Reservation (NCIR). We would also like to thank the Tribe for providing valuable information including some confidential data held by the Tribe. As an effort to facilitate the technology transfer to the Northern Cheyenne Tribe, a summer interim position for a tribal student was sponsored by a Mickey Leland Energy Fellowship (MLEF) through the DOE, Office of Fossil Energy at Idaho National Engineering and Environmental Laboratory (INEEL). 


\section{Table of Contents}

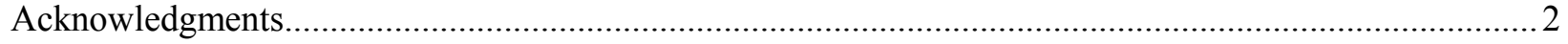

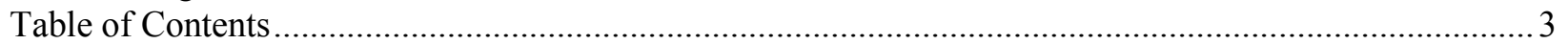

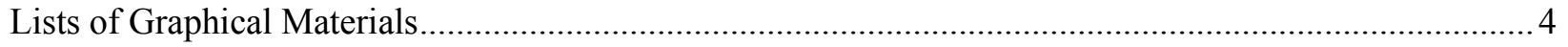

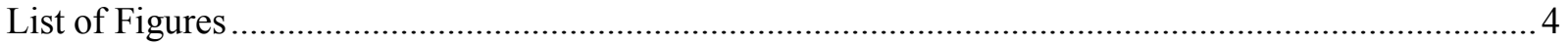

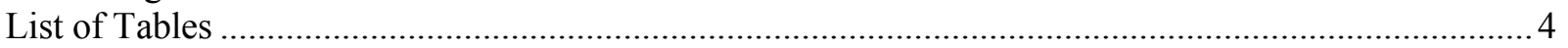

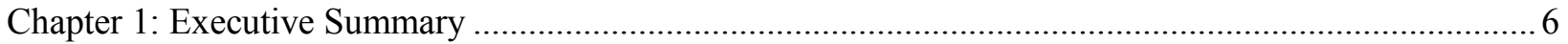

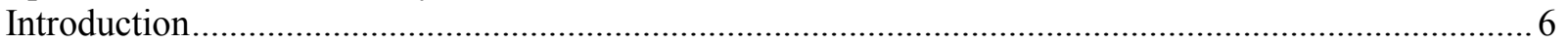

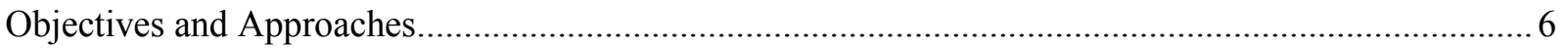

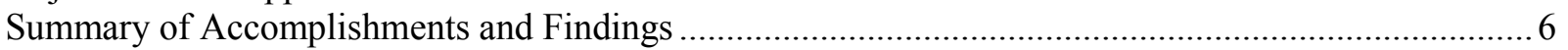

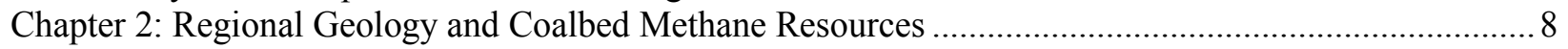

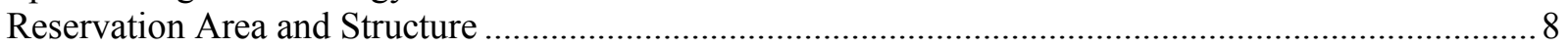

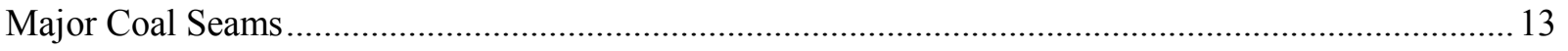

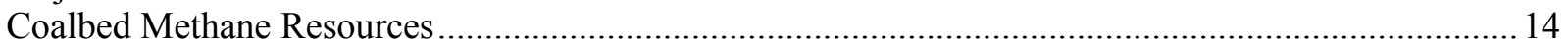

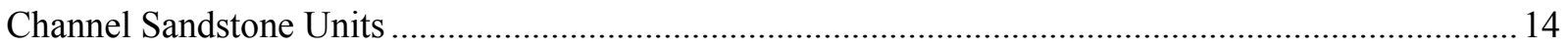

Chapter 3: Assessment of Coalbed Water Resources and Productions ................................................. 16

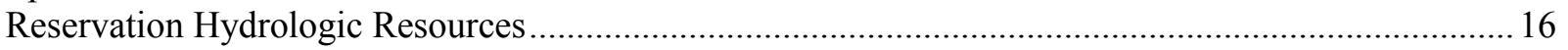

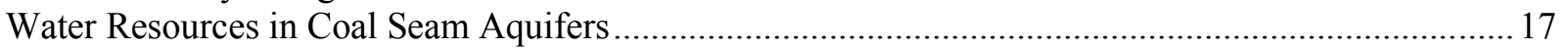

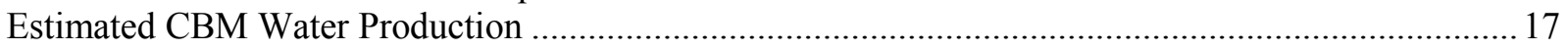

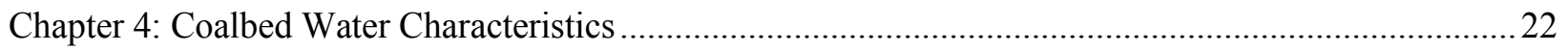

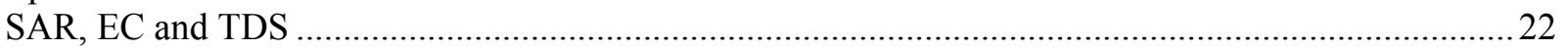

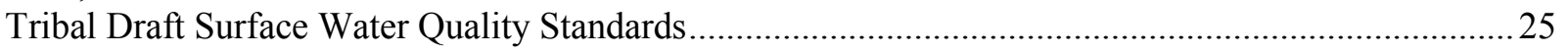

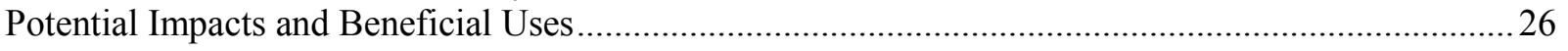

Chapter 5: Economics of Alternative Water Handling Options............................................................ 31

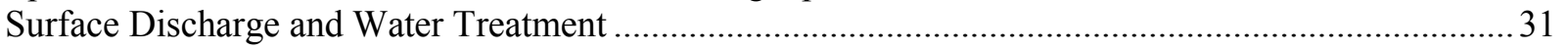

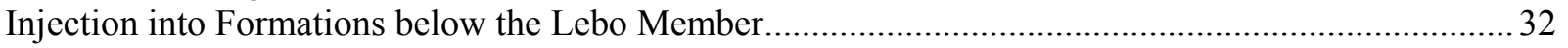

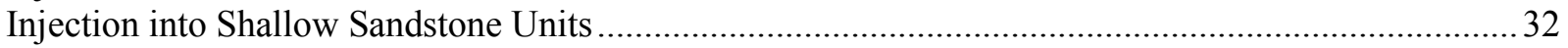

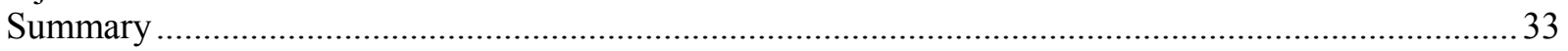

Chapter 6: Injection of CBM Water into Channel Sandstone Units ................................................... 34

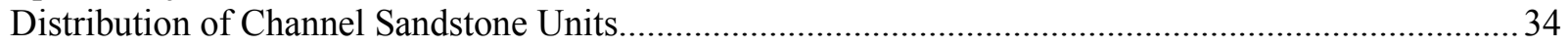

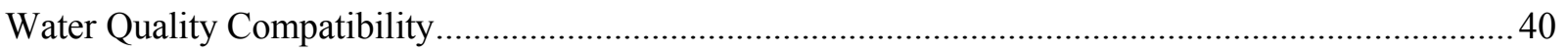

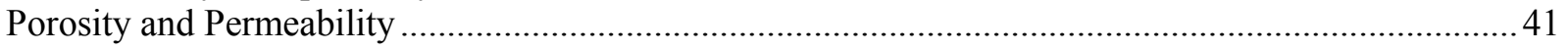

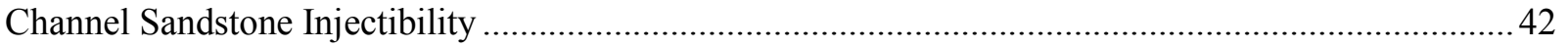

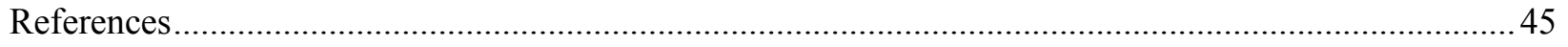




\section{Lists of Graphical Materials}

\section{List of Figures}

Figure 1. Location of the Northern Cheyenne Reservation and other Montana Indian reservations........... 8

Figure 2. Coal stratigraphy in the region of the Northern Cheyenne Reservation...................................... 9

Figure 3. Structure contour map on top of the Lebo Member of the Fort Union Formation. Contour

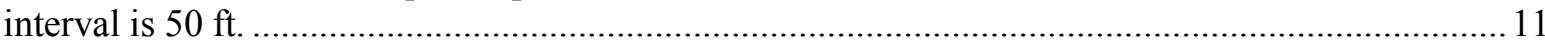

Figure 4. En echelon normal faults in the Northern Cheyenne Reservation area. These are probably the southeastern extension of the Lake Basin Fault Zone. ' $U$ ' and 'D' designate up- and down-thrown

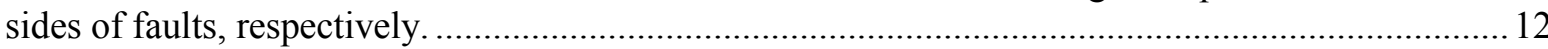

Figure 5. Lineaments (dash-dot pattern) from ASTER imagery and known faults (solid lines) in the Northern Cheyenne Reservation area. ...................................................................................... 13

Figure 6. Typical log expression of channel sandstones in the Tongue River Member of the Fort Union Formation. Stratigraphic cross section of sandstone ' $D$ '.

Figure 7. Paleo channels interpreted from sandstone isopach maps of sandstones in the Tongue River Member of the Fort Union Formation......................................................................................... 15

Figure 8. Simulated water productions of high, low, and average type wells for the Cook coal seam. .... 18

Figure 9. Simulated water productions of high, low, and average type wells for the Wall coal seam. ..... 19

Figure 10. Simulated water productions of high, low, and average type wells for the Pawnee coal seam.

Figure 11. Simulated water productions of high, low, and average type wells for the Knobloch coal seam.

Figure 12. Simulated water productions of high, low, and average type wells for the Rosebud-Mckay coal

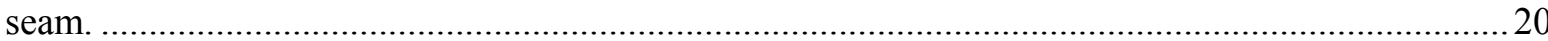

Figure 13. Simulated water productions of high, low, and average type wells for the Flowers-Goodale

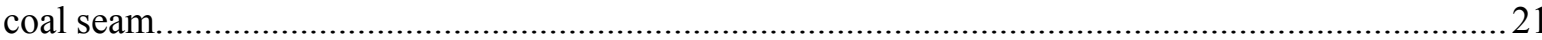

Figure 14. Total Dissolved Solids (TDS) and Sodium Adsoption Ratio (SAR) vs. water sample depth. . 23

Figure 15. Constituents of CBM-related geochemical signature of the six coalbed water samples......... 25

Figure 16. The geochemical signatures of Sample $1 \& 2$ in comparison with the average constituent concentrations of the water samples from the Anderson coalbed in the CX Field and the Rosebud-

Mckay-Robison coal formation in the Colstrip area.................................................................... 25

Figure 17. The salinity and SAR values of the six samples in comparison with the potential reduction in rate of water infiltration as affected by salinity and sodium adsorption ratio (adapted from Rhoades, 1977; Oster and Schroer, 1979; and Ayers and Westcot, 1985)..................................................27

Figure 18. Relationship between relative crop yield and irrigation water salinity for six sample crops

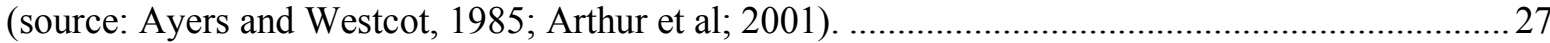

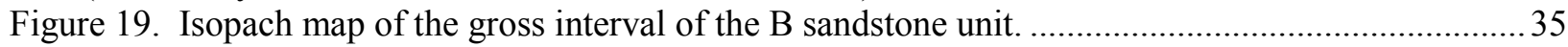

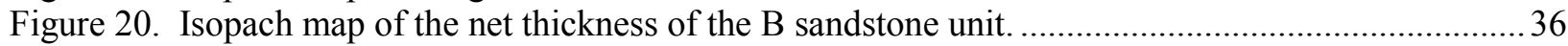

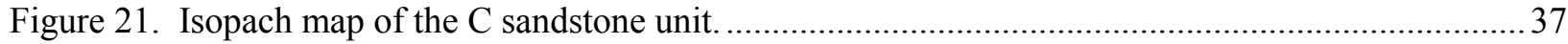

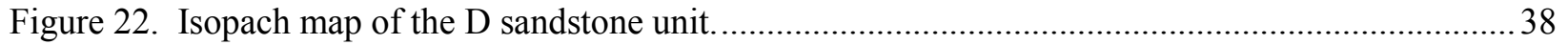

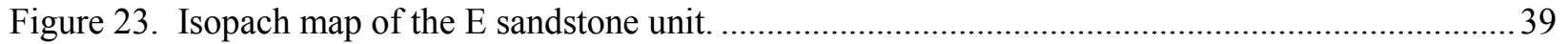

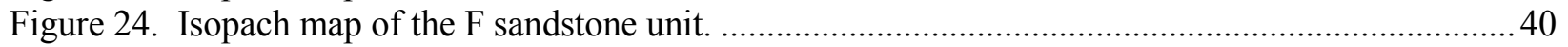

Figure 25. Estimated injectivity as a function of sand thickness and permeability. ............................. 43

Figure 26. The Hall plot for assessing the injection performance. ........................................................ 44

\section{List of Tables}

Table 1. Northern Cheyenne tributary - monthly averages of water-quality parameters, non-continuous

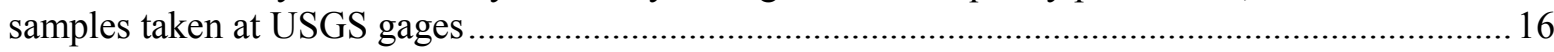

Table 2. Water quality of the alluvium in the region of the Northern Cheyenne Reservation.................. 17

Table 3. Estimated groundwater resources of the coal seams within the Northern Cheyenne Reservation

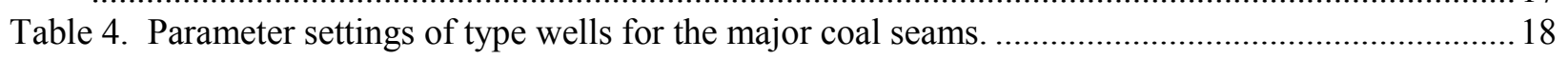




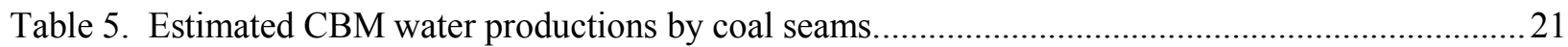

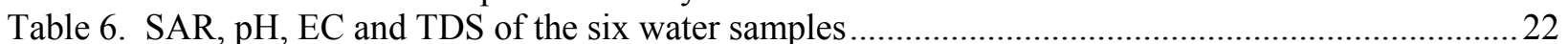

Table 7. Major chemical constituents in the six water samples..........................................................24

Table 8. Water quality comparison of the NC water samples with the average CBM water in PRB.......24

Table 9. Proposed numeric standards for EC, SAR and TDS values applicable to the mainstreams of the

Tongue River, Rosebud Creek and their tributaries....................................................................... 26

Table 10. Summary of sensitivity ratings of thirty-one native and culturally significant plant species of the Northern Cheyenne Reservation to soil solution salinity (EC), exchangeable sodium percentage

(ESP), flooding, and changes in soil $\mathrm{pH}$.

Table 11. Northern Cheyenne current and anticipated water uses.......................................................... 30

Table 12. Treatment technologies and their effectiveness on reducing certain constituent types present in

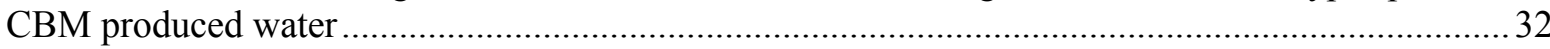

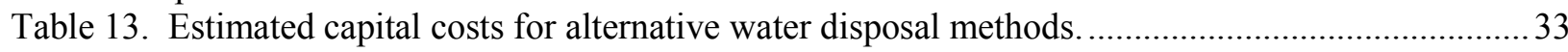

Table 14. Composition of the groundwater used in measuring porosity. ................................................ 41

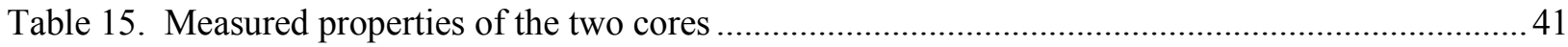

Table 16. Initial water intake capabilities of the sand units.............................................................. 43 


\section{Chapter 1: Executive Summary}

\section{Introduction}

Coalbed methane (CBM) development in the Powder River Basin (PRB) is currently one of the most active gas plays in the United States. Monthly production in 2002 reached about 26 BCF in the Wyoming portion of the basin. Coalbed methane reserves for the Wyoming portion of the basin are approximately 25 trillion cubic feet (TCF). Although coal beds in the Powder River Basin extend well into Montana, including the area of the Northern Cheyenne Indian Reservation, the only CBM development in Montana is the CX Field, operated by the Fidelity Exploration, near the Wyoming border. The Northern Cheyenne Reservation is located on the northwest flank of the PRB in Montana with a total land of 445,000 acres. The Reservation consists of five districts, Lame Deer, Busby, Ashland, Birney, and Muddy Cluster and has a population of 4,470 according to the 2000 Census. The CBM resource represents a significant potential asset to the Northern Cheyenne Indian Tribe. Methane gas in coal beds is trapped by hydrodynamic pressure. Because the production of CBM involves the dewatering of coalbed to allow the release of methane gas from the coal matrix, the relatively large volume of the co-produced water and its potential environmental impacts are the primary concerns for the Tribe.

Presented in this report is a study conducted by the Idaho National Engineering and Environmental Laboratory (INEEL) and the Montana Bureau of Mines and Geology (MBMG) in partnership with the Northern Cheyenne Tribe to assess the Tribe's CBM resources and evaluate applicable water handling options. The project was supported by the U.S. Department of Energy (DOE) through the Native American Initiative of the National Petroleum Technology Office, under contract DEAC07-99ID13727. Matching funds were granted by the MBMG in supporting the work of geologic study and mapping conducted at MBMG.

\section{Objectives and Approaches}

The overall project objectives are two-fold: (1) to conduct an analysis of the coalbed methane production potential for coal assets underlying the Northern Cheyenne Indian Reservation; and (2) to evaluate options for handling the co-produced water to minimize impacts on the environment, in which the emphasis is placed on the re-injection of produced water as opposed to other water disposal options.

To accomplish the objectives, key tasks were identified including a detailed geologic description of coal assets and potential water disposal formations, reservoir simulation to quantify gas and water productions, evaluating CBM water quality, and reviewing multiple water-handling options. MBMG was responsible for an accurate geologic description of the reservation, including detailed stratigraphy and distribution of coals and sandstones in the Tongue River Member of the Fort Union Formation. The reservoir simulation and production/injection forecasts were performed by INEEL. The focus was on water disposal by re-injection into a zone that can preserve the CBM water for beneficial uses.

\section{Summary of Accomplishments and Findings}

The distributions of major coal beds underlying the Reservation have been mapped. The maps were created in the format of ArcView shape file. For the mapped coal beds, their potential of original gas in-place (OGI) was assessed. Restricted by the agreement between the Tribe and project partners, the estimated CBM resources are considered as Tribe's proprietary data and, therefore, are not presented in this report. Besides the assessment of CBM resources, other accomplishments from this project include

- A detailed description of regional geology and stratigraphic column of coal beds underlying the Reservation (Chapter 2),

- Identifying and mapping shallow channel sandstones that are suitable for water disposal by reinjection (Chapter 2 and 6),

- Assessing the water resources in the coal beds (Chapter 3),

- Simulating and forecasting the water productions of type wells for major coal seams (Chapter 3),

- Evaluating CBM water quality and its potential impacts and beneficial uses (Chapter 4),

- Reviewing the economics of alternative water handling options (Chapter 5), 
- Assessing the water injectivity in the identified channel sandstones (Chapter 6).

The water chemistry data of six water samples, collected from the coalbeds underlying the Reservation, were provided by Mike Cannon of the USGS, Helena, Montana. The SAR values of the six samples range from 33 to 66, which is much higher than the average SAR value of 25.5 in the PRB. CBM water underlying the Reservation is in general not suitable for irrigation. Surface discharge of untreated CBM water will certainly have adverse impacts on local soil and native plants. Although, the EPA and the State of Montana currently do not have any numeric criteria for surface water, the Tribe has submitted a Draft Surface Water Quality Standards of the Reservation to the EPA. For the waters in the Tongue River, Rosebud Creek and their tributaries, monthly average values of 3.0 for Sodium Adsorption Ratio (SAR), $2.0 \mathrm{dS} / \mathrm{m}$ for Electrical Conductivity (EC), and $1320 \mathrm{mg} / \mathrm{L}$ for Total Dissolved Solids (TDS) were proposed as the numeric criteria for the non-irrigation period (November $15^{\text {th }}-$ March $31^{\text {st }}$ ). Even lower numeric criteria were proposed for the irrigation period monthly (April $1^{\text {st }}-$ November $15^{\text {th }}$ ). It is very likely that any surface discharged CBM water on the Reservation will be required to meet the Tribe's Draft Surface Water Quality Standards. However, the quality of CBM water is sufficient for domestic and livestock uses as well as for other anticipated industrial and economic uses.

Four basic options have been evaluated for dealing with CBM produced water: (1) surface discharge with water treatment; (2) direct use without treatment; (3) re-inject the water into formations below the Lebo Member formation, i.e. deeper injection; or (4) re-inject the water into the channel sandstone units above the Lebo Member formation, i.e. shallow injection. Although various treatment technologies for SAR reduction have been tested in the PRB, most of them have not been proven to be economical. Surface discharge will probably not be economical for the Reservation if discharged CBM water is required to meet the Tribe's Draft Surface Water Quality Standards. Deeper injection into formations below the Lebo Member is apparently more expensive than shallow injection into the channel sandstones. More importantly, the valuable resource of CBM water could be degraded by deeper injections.

Therefore, the best option for the Tribe might be a combination of shallow injections with some of the produced water being directly used for livestock watering, domestic, municipal, and commercial uses.

The groundwater resources in the Cook, Pawnee, Wall, and Knobloch coal seams were estimated around 5.1 billion barrels. Because the reservation is highly dissected and many of the coal beds occur only in erosional remnants in ridge areas, well performance could vary significantly for different coal beds and locations. Forecasted by simulation, peak water production rates vary from $9.3 \mathrm{gpm}$ to $52.5 \mathrm{gpm}$ depending on the targeted coalbed and location on the reservation.

A stacked sequence of six paleo-channels has been identified and mapped on the Reservation. The channel sandstones are informally named A-F, from bottom to top, in which Unit A is the basal sandstone in the Tongue River Member. Some of the channel sandstone units are as much as 100' thick. The D unit appears the best in terms of overall sand thickness and areal extent. The top injectivities of unit $\mathrm{B}, \mathrm{C}$, and $\mathrm{D}$ were estimated at 25,67 , and $75 \mathrm{barrel} /$ day-psi, respectively. 


\section{Chapter 2: Regional Geology and Coalbed Methane Resources}

The geologic study and mapping described in this chapter were conducted by Dr. David Lopez's group at the Montana Bureau of Mines and Geology (MBMG). The work was supported in part by the matching funds from the MBMG.

\section{Reservation Area and Structure}

The Northern Cheyenne Reservation is located in SE Montana adjoining the Crow Reservation (Figure 1). The Reservation is in the northwestern part of the Powder River Basin, the part of the Basin that may have CBNG potential.

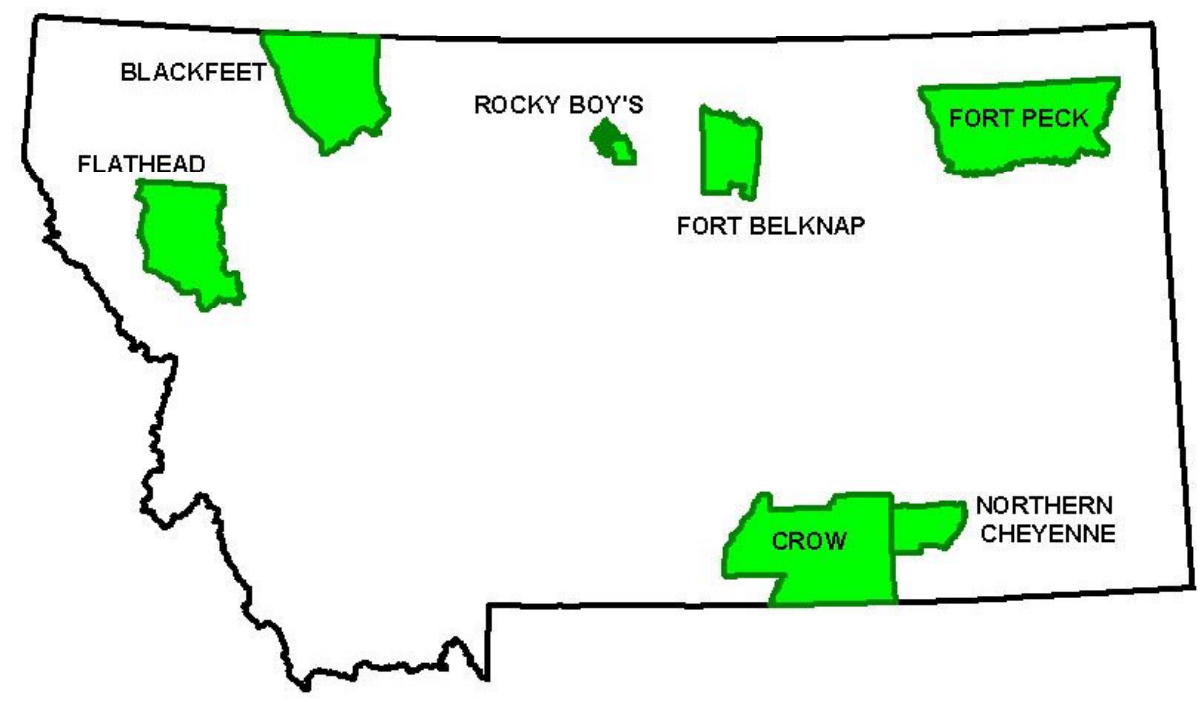

Figure 1. Location of the Northern Cheyenne Reservation and other Montana Indian reservations.

The Reservation area is underlain by rocks of the Paleocene Fort Union Formation, mainly the Tongue River Member. The Fort Union Formation is divisible into three members: the Tullock, Lebo, and Tongue River (Figure 2). The Tullock Member is 250 to 300 feet thick in the area. It is not exposed on the Reservation, but it is present in the subsurface and is penetrated by oil and gas exploration wells. This member consists of interbedded mudstone, argillaceous sandstone, and minor amounts of coal.

The Lebo Member is about 200 feet thick and is exposed only near the western edge of the Reservation. It is mostly mudstone, lesser amounts of sandstone, and impure coal beds. 


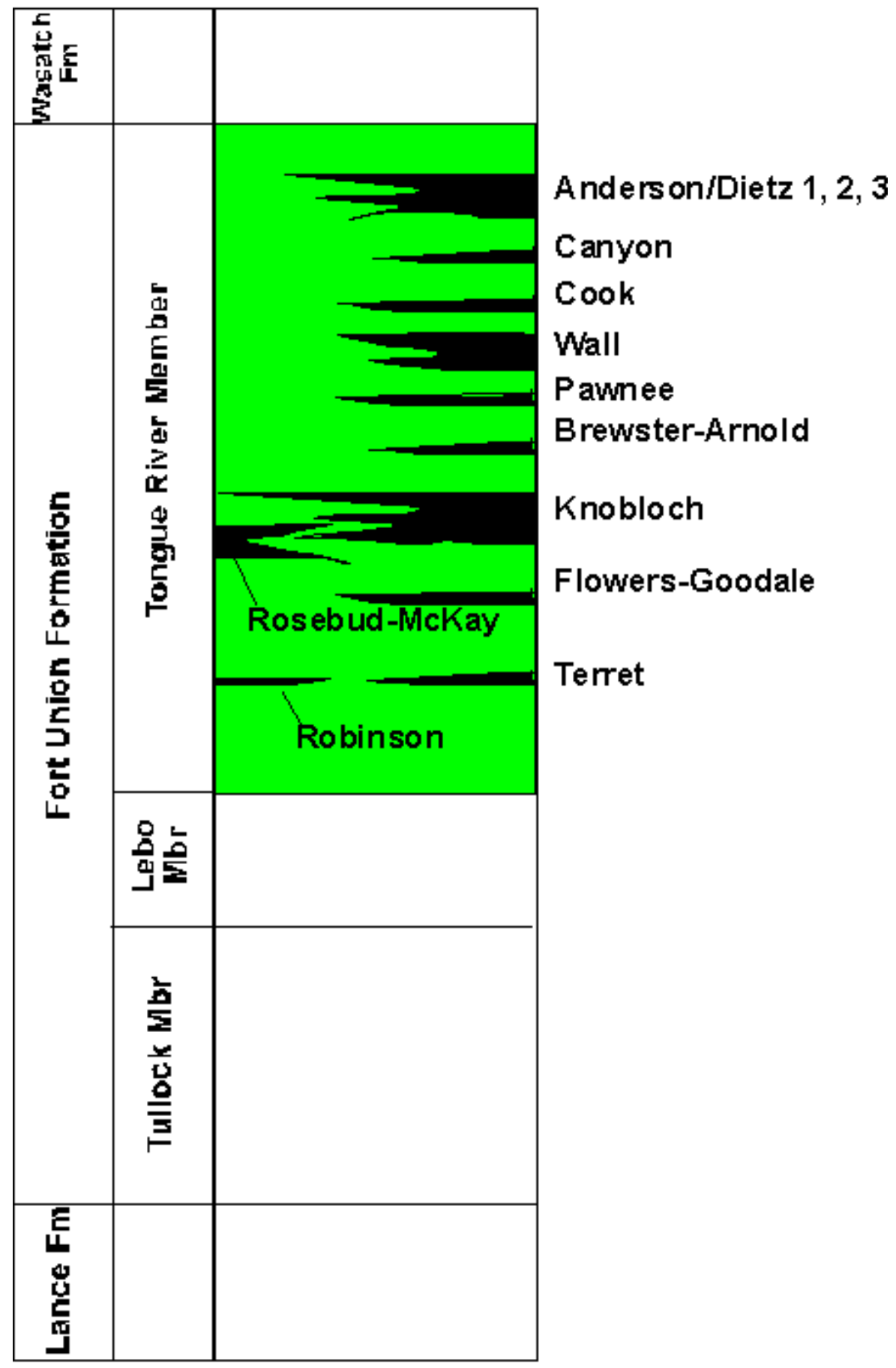

Figure 2. Coal stratigraphy in the region of the Northern Cheyenne Reservation

Over most of the Reservation, the surface exposures are rocks of the Tongue River Member. The Tongue River Member is about 650 feet thick. It is composed of interbedded mudstone, argillaceous sandstone, and coal. There are also several thick clean channel sandstone units within this member. Coal beds in the Tongue River Member of the Ft. Union Formation are extensive in the Reservation area. Up to 8 coal beds are present, some as thick as 80 feet (see figure 2). Confidential data, held by the Northern Cheyenne Tribe, was used to describe the coal beds for the purpose of providing the basic data required for the modeling of water production associated with coal-bed natural gas development. The reservation is highly dissected and many of the coal beds occur only in erosional remnants in ridge areas, being breached in the valleys of Rosebud Creek, the Tongue River, and other major streams. Extensive areas of 
clinker occur on the Reservation because all the coal beds have been burned to varying extents along their outcrop bands.

Structural mapping on top of the Lebo Shale Member of the Fort Union Formation for the Northern Cheyenne Reservation region illustrates that the structural axis of the Powder River Basin trends northerly across the eastern part of the reservation (Figure 3). Isolated structural closures just east of the reservation and along the northern border may have formed traps where natural gas from coal beds may have migrated into sandstone reservoirs. Southeast-trending anticlinal ridges may provide combination structural-stratigraphic traps in Fort Union channel sandstone within the Reservation.

A system of northeast-trending, en echelon, normal faults is present in the northwest corner of the Northern Cheyenne Reservation (Figure 4). These faults are thought to be an extension of the Lake Basin Fault Zone of central Montana. Lineaments that may represent fracture systems are in two sets: one is parallel and sub-parallel to the faults mapped in the area; the other set is generally orthogonal to this set (Figure 5). 


\section{Structure Contour Map on Top of Lebo Member}

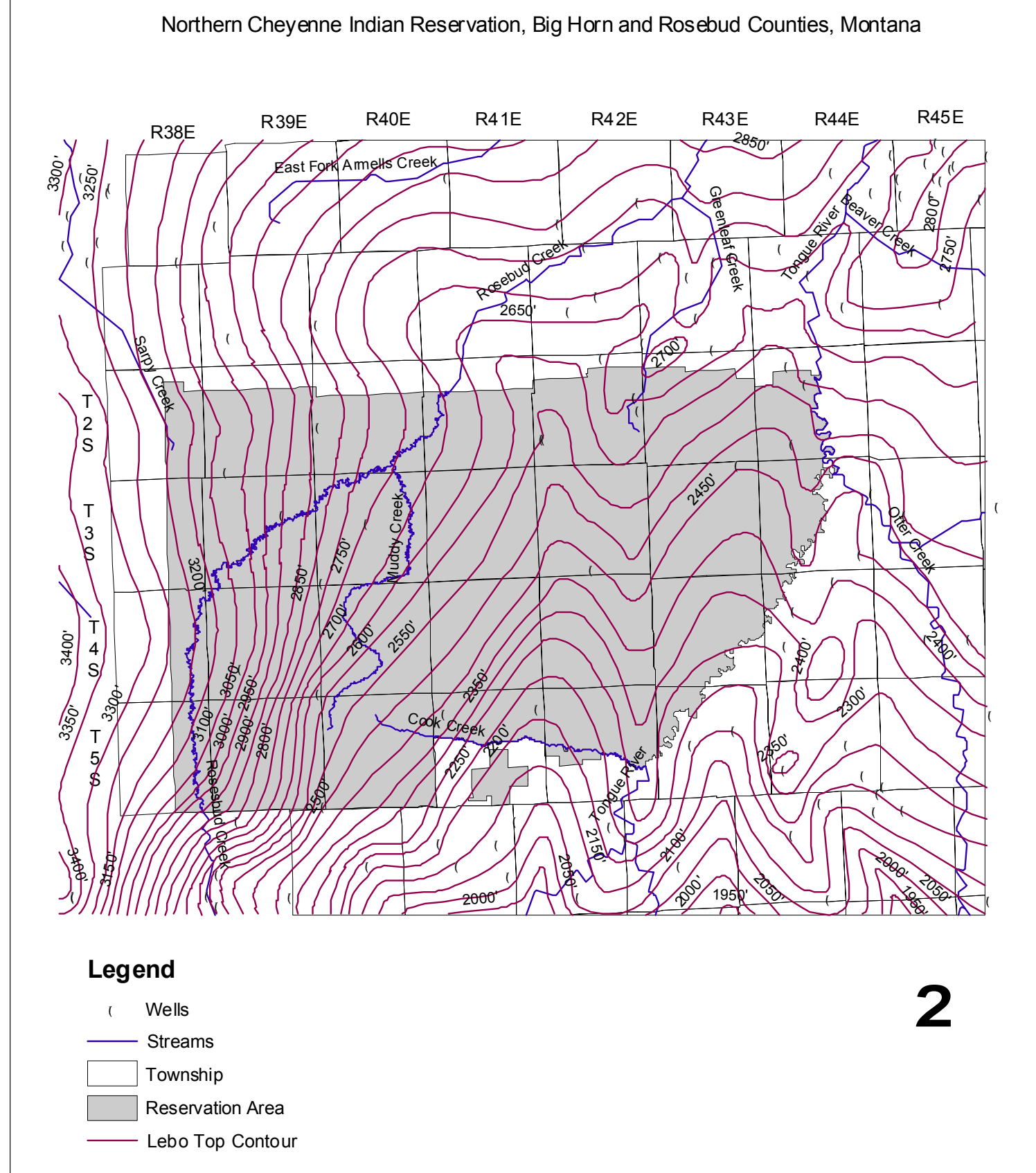

Figure 3. Structure contour map on top of the Lebo Member of the Fort Union Formation. Contour interval is $50 \mathrm{ft}$. 


\section{En echelon Normal Faults}

Northern Cheyenne Indian Reservation, Big Horn and Rosebud Counties, Montana

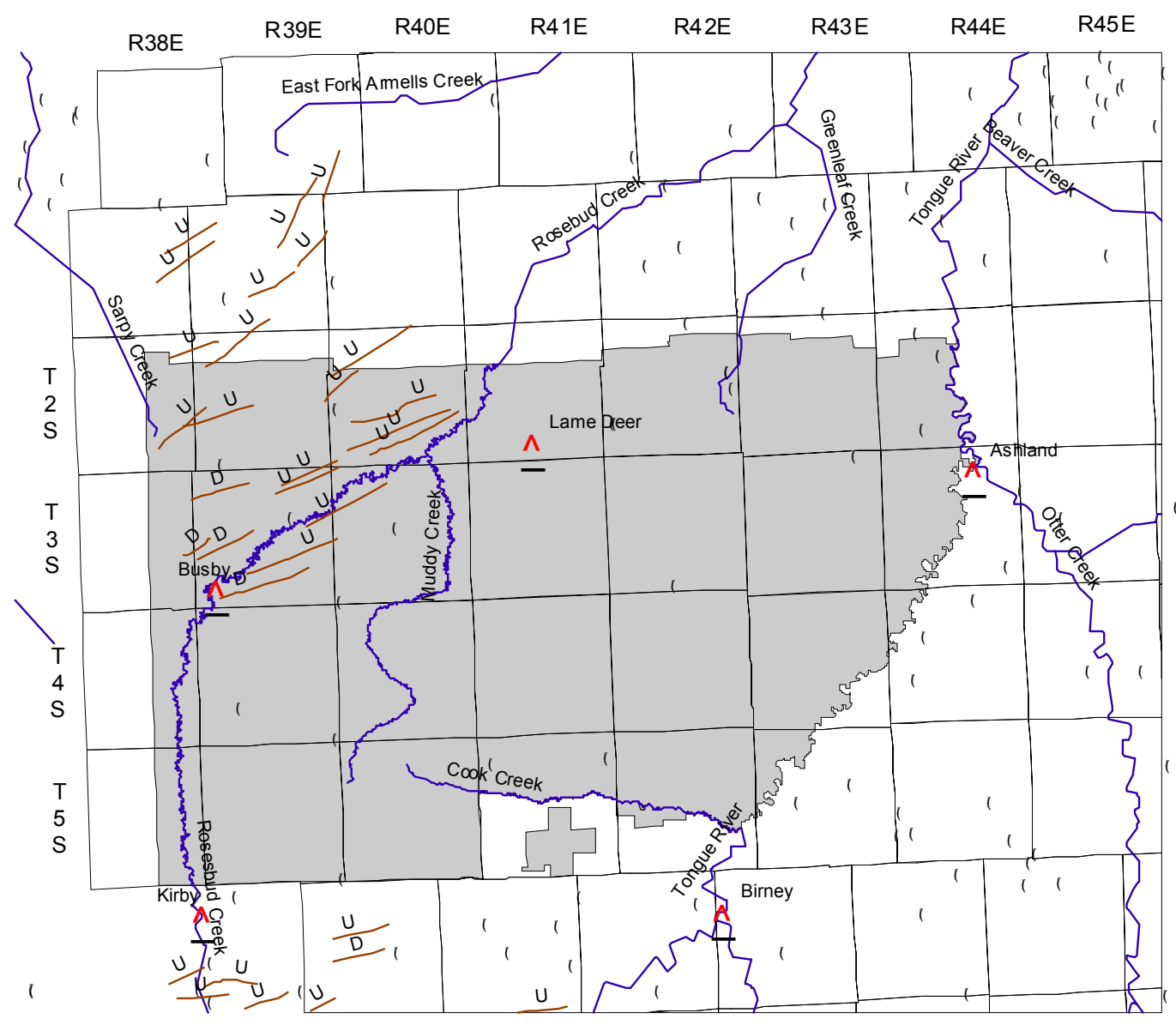

\section{Legend}
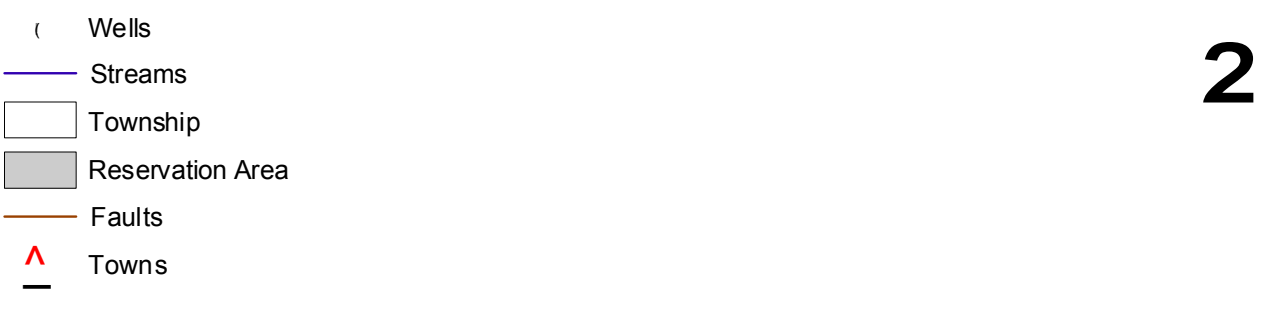

Figure 4. En echelon normal faults in the Northern Cheyenne Reservation area. These are probably the southeastern extension of the Lake Basin Fault Zone. ' $U$ ' and ' $D$ ' designate up- and down-thrown sides of faults, respectively. 


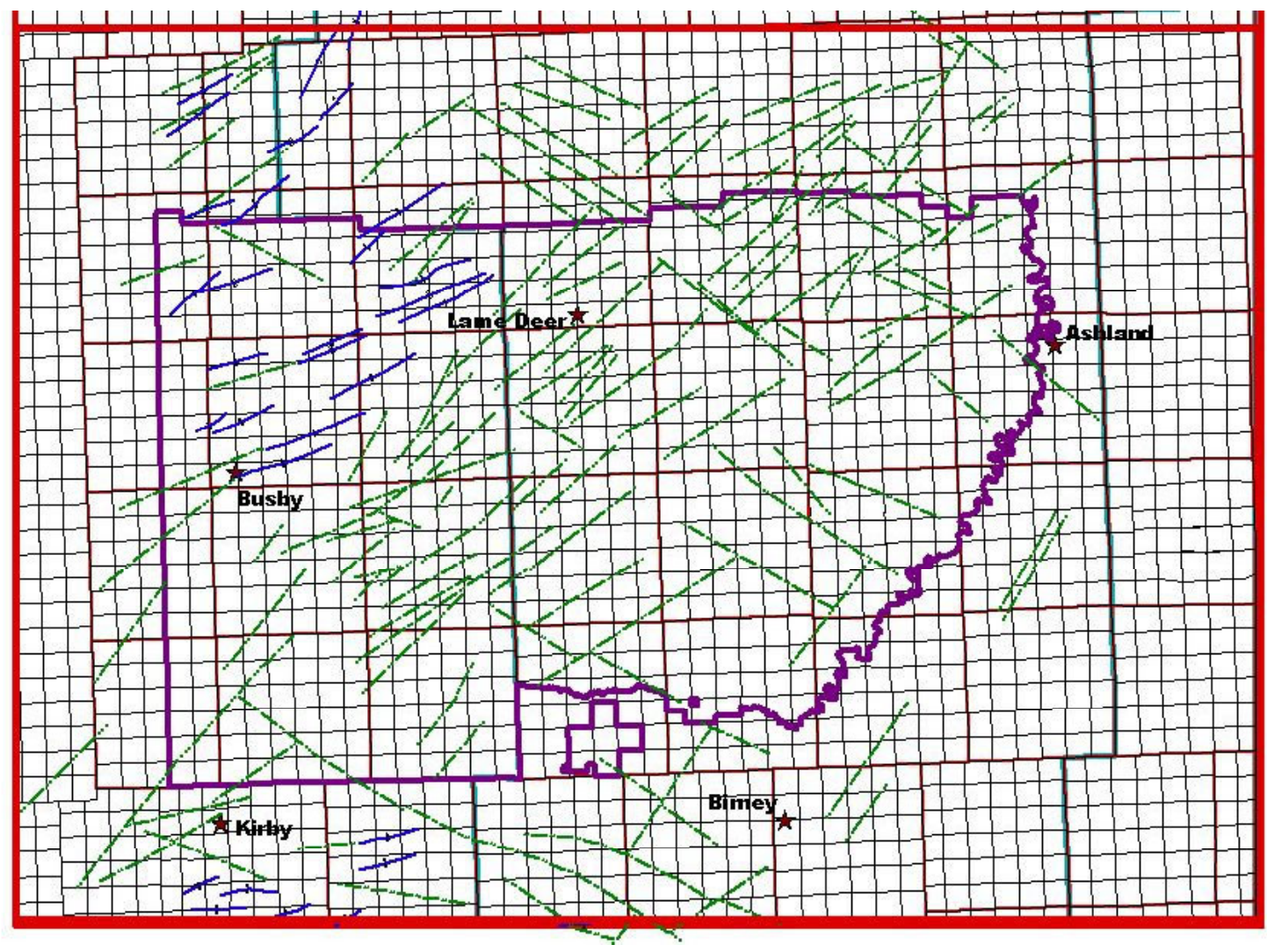

Figure 5. Lineaments (dash-dot pattern) from ASTER imagery and known faults (solid lines) in the Northern Cheyenne Reservation area.

\section{Major Coal Seams}

The uppermost coal beds, the Anderson/Dietz and Canyon, occur only on the highest ridges and are largely burned. These beds are the main target zones in the only coal bed natural gas development in Montana, the CX Field, northeast of Sheridan Wyoming. The Anderson/ Dietz and Canyon beds have little or no potential for coal bed natural gas development on the Northern Cheyenne Reservation because of their shallow depth and extensive burning. Therefore, thickness maps of these coal beds were not made for this project.

The Cook coal bed also occurs only in the major ridge area trending northeasterly across the central part of the Reservation. The maximum thickness is about 20 feet. The maximum depth to this coal bed is about 600 feet in the area of the highest elevations. It crops out along the valleys of Rosebud Creek and the Tongue River and is partially burned.

The Wall coal bed is also present in the topographically high area in the central part of the Reservation. It reaches a maximum thickness of about 50 feet. The maximum depth in the area of highest elevation is about 800 feet. The Wall coal crops out along the valleys of Rosebud Creek and the Tongue River and is partially burned along its outcrop.

The Pawnee coal bed is also present in the same area as the coals described above. The maximum thickness of the Pawnee is about 40 feet and is at a maximum depth of about 900 feet along the ridge crest in the south-central part of the Reservation. The Pawnee also crops out along the valleys of Rosebud Creek and the Tongue River and is partially burned along its outcrop band.

The Brewster-Arnold bed is thin and lenticular and could not be mapped in detail because of limited control.

The Knobloch coal bed is the thickest coal bed in the Reservation area. It is exposed in the Tongue River valley bottom on the east side of the Reservation and in the Rosebud Creek area near the 
town of Busby. It reaches a maximum thickness of about 85 feet and is at a maximum depth of 1200 feet in the area of highest elevations in the south-central part of the Reservation. The Knobloch is partly burned along the outcrop band.

The Rosebud-McKay coal beds occur only in the northwest corner and along the north-central boundary of the Reservation. This coal bed reaches a maximum thickness of about 20 feet along the northern boundary of the Reservation. It is about 12 feet thick in the northwest corner and occurs at a maximum depth of about 500 feet.

The Flowers-Goodale coal occurs only in the subsurface in the eastern half of the Reservation. This coal could not be mapped because of limited control; it occurs at a depth too deep for strip mining, so coal exploration drilling was not conducted. It reaches a maximum thickness of about 20 to 25 feet and is at a maximum depth of about 1300 feet in the area of greatest elevations in the south central part of the Reservation. In the Tongue River Valley, it is at a depth of 200 to 300 feet.

The Robinson and Terret beds are present only in the subsurface. The Robinson coal occurs only in the northwest corner of the reservation and pinches out to the southeast and is absent southeast of Rosebud Creek. It has a maximum thickness of about 20 feet and occurs at a maximum depth of about 700 feet. The Terret, which is approximately stratigraphically equivalent to the Robinson, occurs in the southeast part of the Reservation. It was not mapped because of lack of control. It appears to reach a maximum thickness of about 10 feet and occurs at depths similar to the Robinson.

\section{Coalbed Methane Resources}

For the major coal seams discussed above, the potential of original gas in place (OGI) was assessed. Restricted by the agreement between the Tribe and project partners, the estimated CBM resources are considered as Tribe's proprietary data and should not be disclosed to public. By using the ArcView contour maps of coal seam thickness distributions overlapped with the section-line map, histogram distributions of coal seam thickness versus number of section were generated on MS Excel spreadsheets. The OGI in each section was estimated by a simple analytic model based on average data of adsorption isotherm, formation pressure, thickness, cleat porosity, and initial water saturation. An Excel macro was created to calculate the total OGI of a coal seam according to its histogram distribution and the OGIs in sections.

\section{Channel Sandstone Units}

Six channel sandstone units (Figure 6) were mapped on the reservation, which form a stacked sequence of paleo-channels. The channel sandstones are informally named A-F, from bottom to top; 'A' being the basal sandstone in the Tongue River Member. Some of the channel sandstone units are as much as 100' thick. Figure 7 shows the drainage patterns of these stacked channels as interpreted from sandstone isopach maps. The coincidence of the traces of the channels through time implies that there may have been paleo-structural control on their locations.

Geophysical log data and lab analysis indicate that porosity in the channel sandstones is as great as $30 \%$. Permeability appears to be good, but has not yet been determined. These channel sandstone units are good candidates for water disposal by injection. Fracturing will increase the permeability of these units and enhance their use for water injection. ASTER satellite imagery was used to predict the presence of fractures. A fracture map interpreted from imagery lineaments shows areas where the fracturing may be present and would enhance the permeability of channel sandstone units (Figure 5). 


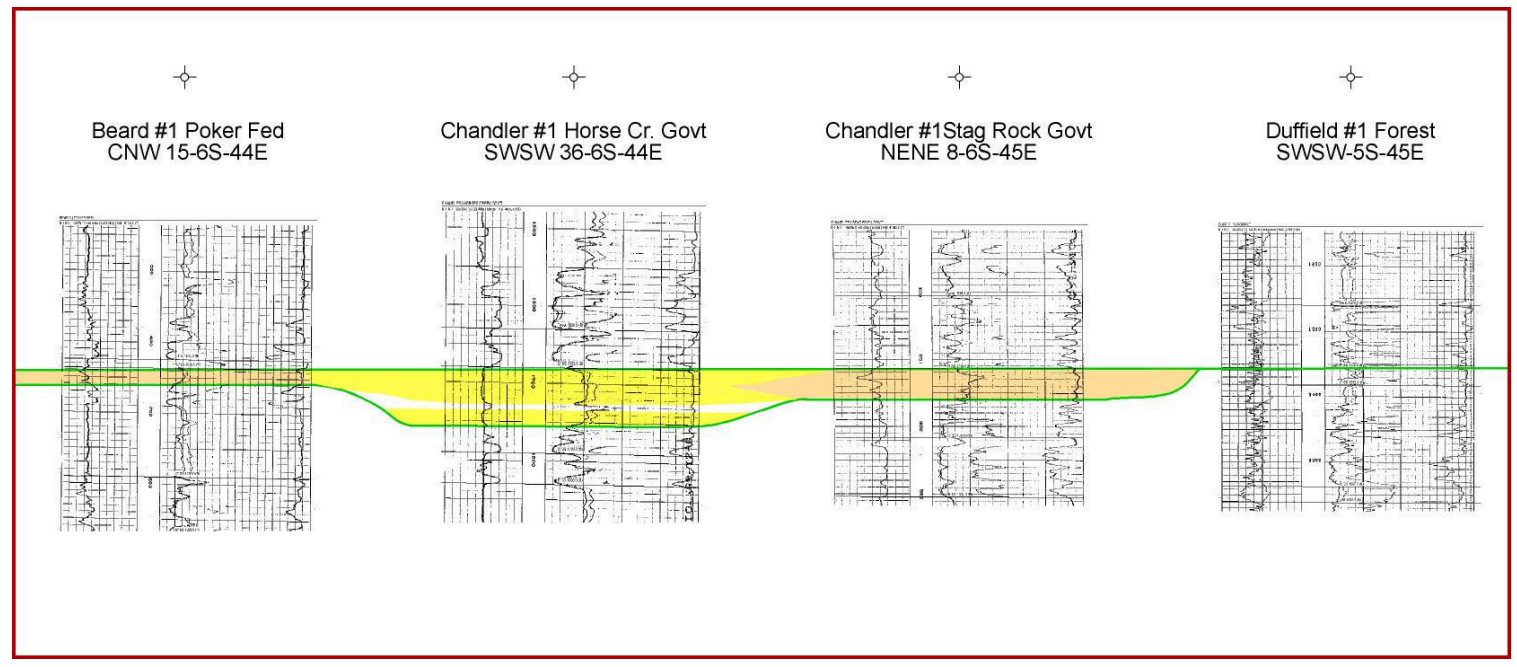

Figure 6. Typical log expression of channel sandstones in the Tongue River Member of the Fort Union Formation. Stratigraphic cross section of sandstone ' $D$ '.

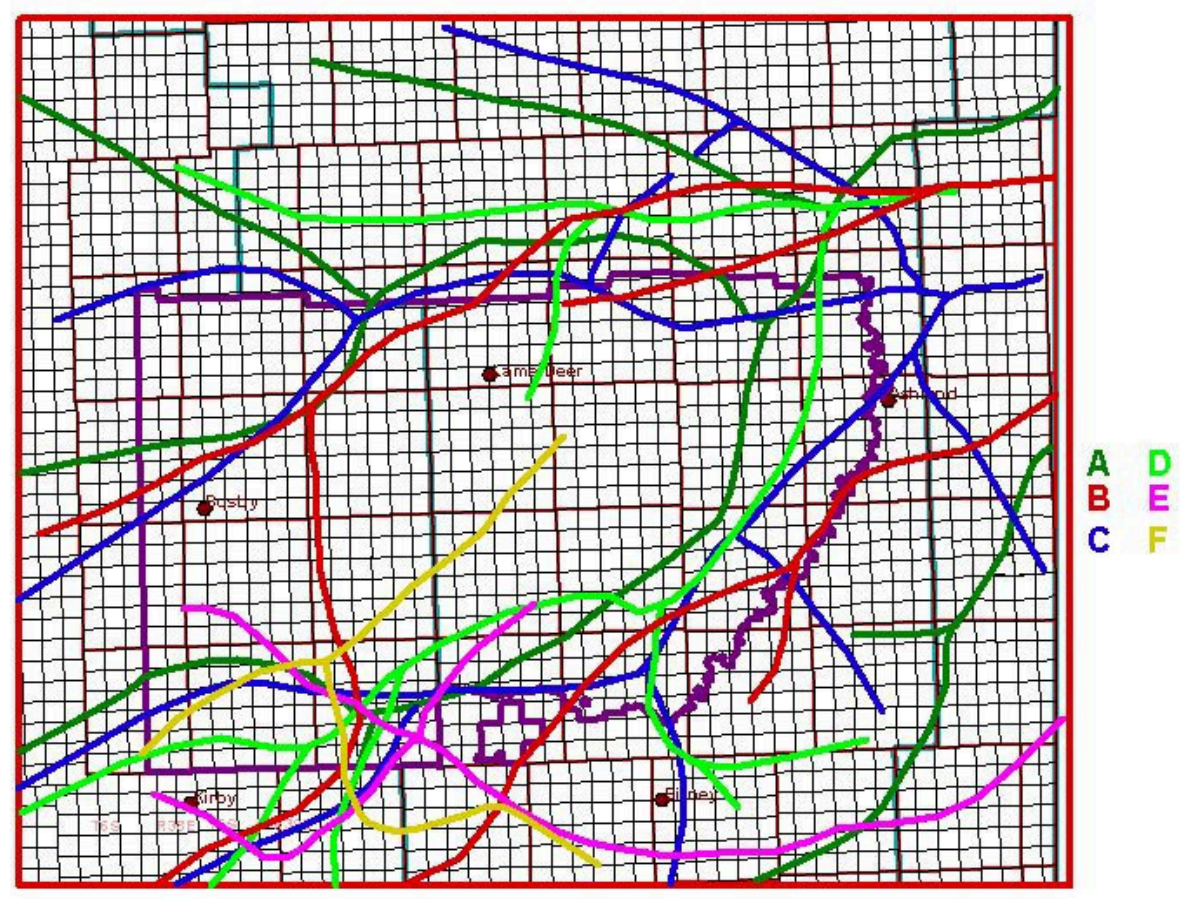

Figure 7. Paleo channels interpreted from sandstone isopach maps of sandstones in the Tongue River Member of the Fort Union Formation. 


\section{Chapter 3: Assessment of Coalbed Water Resources and Productions}

The accomplishment of mapping the distribution of coalbeds makes it possible to accurately assess the coalbed water resources underlying the Reservation. Based on geologic description, isotherm data, and other required information, different models have been constructed and simulated to forecast CBM well performance in different coalbeds. The simulation shows that the water production from a CBM well can vary dramatically depending on its targeted coalbed and location on the reservation.

\section{Reservation Hydrologic Resources}

Hydrological resources on the reservation consist of surface water flow from several rivers and their associated tributaries, and groundwater in a variety of geologic formations, including coalbed aquifers. An overview of the reservation's water resources can be found in a Tribe's report published in 2002, 'The Northern Cheyenne Tribe and Its Reservation'. The reported groundwater resources of the Reservation include the Madison Group of Mississippian age, the Fox Hills Sandstone and Hell Creek Formation of Cretaceous age, the Fort Union Formation of Tertiary age, and the valley fill-alluvium of Quaternary age. The information presented in the report was obtained primarily from the Shallow Groundwater Study conducted by the HKM Associates in 1983. However, no comprehensive assessment of coalbed water resources of the Reservation was conducted in previous studies.

Of particular importance is the water quality of the surface water and alluvial groundwater within the Reservation. It is these water resources that may be impacted by CBM development. Many drinking water wells on the Reservation are completed in the alluvium. Therefore, surface discharged or used CBM water must be regulated so that it does not degrade the surface and alluvium water quality. The sampled water quality of surface water from the Northern Cheyenne tributaries is provided in Table 1 based on the USGS monitoring data. The Tribe has conducted an evaluation for its groundwater from 1973 through 1977. The description of alluvial water quality (Table 2) is based on the data collected during that study period. The water is generally suitable for drinking with respect to the Primary Drinking Water Standards but often does not meet the Secondary Drinking Water Standards. The water is acceptable for livestock use and is properly suitable for irrigation for saline tolerant crops, while special irrigation practices are required to prevent soil salinity and infiltration reduction problems.

Table 1. Northern Cheyenne tributary - monthly averages of water-quality parameters, non-continuous samples taken at USGS gages

\begin{tabular}{|c|c|c|c|c|c|c|}
\hline Tributary & USGS Gage & Location in Montana & Sampling Period & $\begin{array}{l}\text { Bicarbonate as } \\
\mathrm{HCO} 3, \mathrm{mg} / \mathrm{L}\end{array}$ & & \\
\hline Tongue River & 06306300 & at Stateline & 1985-1999 & 243 & & \\
\hline Bighorn River & 06294000 & near Hardin & 1969-1999 & & & \\
\hline Otter Creek & 06307740 & near Ashland & 1974-1995 & & & \\
\hline Hanging Woman Creek & & near Birney & 1974-1995 & & & \\
\hline Prairie Dog Creek & 06307528 & near Biney & $1978-1983$ & & & \\
\hline Rosebud Creek & 06295100 & near Kirby & $1982-1988$ & & & \\
\hline Tributary & Calcium, mg/L & "Magnesium, mg/L & "Sodium, mg/L & "Chloride, mg/L & Sulfate, $\mathrm{mg} / \mathrm{L}$ & $\begin{array}{l}\text { Alkalinity as } \\
\mathrm{CACO}, \mathrm{mg} / \mathrm{L}\end{array}$ \\
\hline Tongue River & $33.2-71$ & $10.3-45$ & $6.9-34$ & $1.4-4.2$ & $30-180$ & $\sim 210$ \\
\hline Bighorn River & $55.6-76.7$ & $21.8-37.6$ & $20.4-88.6$ & $1.8-5.3$ & 83-308.1 & \\
\hline Otter Creek & $61.5-100.5$ & $94-183.6$ & 223.7-431.8 & $8.9-21.6$ & $708.9-1289.1$ & \\
\hline Hanging Woman Creek & $78.6-122.2$ & $92.1-140.9$ & $248.6-387.3$ & $10-26.0$ & $754.5-1166.4$ & \\
\hline $\begin{array}{l}\text { Prairie Dog Creek } \\
\text { Rosebud Creek }\end{array}$ & $26-78$ & $26-180$ & $12-120$ & $4.0-9.0$ & $100-750$ & \\
\hline Tributary & "PH, Lab & SC, microsiemens/cm & $\begin{array}{l}\text { Hardness as } \\
\mathrm{CA} 03, \mathrm{mg} / \mathrm{L}\end{array}$ & "TDS, mg/L & SAR & \\
\hline Tongue River & $7.9-8.4$ & $292-698$ & & & & \\
\hline Bighorn River & $8.0-8.4$ & $490-794.9$ & 231.2-344.4 & & $0.6-2.0$ & \\
\hline Otter Creek & $8.0-8.5$ & $1781.4-3180.7$ & $507.1-1025.7$ & 1189.9-2428.6 & $3.7-6.1$ & \\
\hline Hanging Woman Creek & $7.9-8.5$ & $1669.7-2855.3$ & $580-861.4$ & $1375-2221.4$ & $4.1-6.0$ & \\
\hline Prairie Dog Creek & $\sim 7.4$ & $297-1860$ & $170-940$ & $249-1380$ & $0.4-1.8$ & \\
\hline Rosebud Creek & & $955-1340$ & & & & \\
\hline
\end{tabular}

Data Source: The Northern Cheyenne Tribe and Its Reservation, 2002 
Table 2. Water quality of the alluvium in the region of the Northern Cheyenne Reservation

\begin{tabular}{|l|c|c|c|c|}
\hline \multicolumn{1}{|c|}{ Constituent } & Rosebud Creek & Muddy Creek & Lame Deer Creek & Tongue River \\
\hline \hline TDS, $\mathrm{mg} / \mathrm{L}$ & $374-2048$ & $1082-1574$ & $558-1144$ & $527-3277$ \\
\hline CaCO3, mg/L & $140-1225$ & $664-955$ & $450-626$ & $35-946$ \\
\hline Sulfate, $\mathrm{mg} / \mathrm{L}$ & $67-1370$ & $313-731$ & $119-361$ & $0-1893$ \\
\hline Nitrate, $\mathrm{mg} / \mathrm{L}$ & $0-4.0$ & $0-1.0$ & $1.0-4.3$ & $0.1-6.2$ \\
\hline Fluoride, $\mathrm{mg} / \mathrm{L}$ & $0-1.3$ & $0.5-1.5$ & $0.8-2.0$ & $0.3-6.4$ \\
\hline Adjusted SAR & $0-34$ & $5.2-6.0$ & $5.2-6.0$ & $4.3-51$ \\
\hline No. well tested & 17 & 5 samples & 4 & 12 \\
\hline
\end{tabular}

Data Source: The Northern Cheyenne Tribe and Its Reservation, 2002

\section{Water Resources in Coal Seam Aquifers}

The water volume in a specified coal seam was simply estimated according to its isopach map and cleat porosity where an average porosity of $2 \%$ was assumed. The coal cleat is believed to be initially saturated with water. Coal seam isopach maps are regarded as Tribe's confidential data and, therefore, are not included in this report. The estimated water resources of the major coal seam aquifers within the Reservation are provided in Table 3. By overlapping the isopach maps with the section-line map, histogram distributions of coal seam thickness versus number of sections were generated. For a given coal seam, its histogram distribution of thickness-section was used to calculate the total in-place water volume. The estimated groundwater resources in the Cook, Pawnee, Wall, and Knobloch coal seams range from 0.789 to 2.09 billion barrels. Because of insufficient data, no estimations of water resources were made for the Brewster-Arnold, Flowers-Goodale, Rosebud-McKay, Robinson, and Terret coal seams.

Table 3. Estimated groundwater resources of the coal seams within the Northern Cheyenne Reservation

\begin{tabular}{|c|c|c|c|c|}
\hline Coal Seam & $\begin{array}{c}\text { Thickness, } \\
\mathrm{ft}\end{array}$ & $\begin{array}{c}\text { Porosity, } \\
\%\end{array}$ & Total Acres, acres & $\begin{array}{c}\text { Groundwater Resource, } \\
\text { Billion Barrels }\end{array}$ \\
\hline \hline Cook & $5^{\prime}-20^{\prime}$ & 2 & 361,600 & 0.789 \\
\hline Wall & $5^{\prime}-50^{\prime}$ & 2 & 362,880 & 1.28 \\
\hline Pawnee & $10^{\prime}-40^{\prime}$ & 2 & 356,480 & 0.953 \\
\hline Brewster-Arnold & $\sim$ & $\sim$ & $\sim$ & $\sim$ \\
\hline Knobloch & $20^{\prime}-70^{\prime}$ & 2 & 360,960 & \\
\hline Flowers-Goodale & & & & \\
\hline Rosebud-McKay & & & & \\
\hline Robinson & & & & \\
\hline Terret & & & & \\
\hline
\end{tabular}

\section{Estimated CBM Water Production}

The estimate of CBM water production is mainly conducted by numerical simulation because no $\mathrm{CBM}$ well has been drilled on the Reservation to date. However, simulation results were examined and compared with the historical production data from the CBM wells in the CX Field and other wells in Wyoming. Different models have been constructed and simulated to forecast CBM well performance in different coalbeds. A sensitivity study was also performed to evaluate the impacts of permeability, net pay thickness, coal depth, and Langmuir-isotherm parameters on gas and water productions. All simulation work was performed on the COMET2 CBM simulator, which was developed by Advanced Resources International. COMET2 can model single gas as well as binary gas mixtures $\left(\mathrm{CH}_{4}-\mathrm{N}_{2}\right.$ or $\mathrm{CH}_{4}$ $\mathrm{CO}_{2}$ ). Because the reservation is highly dissected and many of the coal beds occur only in erosional remnants in ridge areas, well performance can vary significantly depending on its targeted coalbed and location on the reservation. 
To provide representative ranges of potential water production, high and low production type wells were constructed for major coal seams. Table 4 lists some of the parameter settings for different type wells. A 160-acre well spacing was used for all cases. The forecasted water production rates and cumulative water production of type wells for the Cook, Wall, Pawnee, Knobloch, Rosebud-McKay, and Flowers-Goodale coal seams are given in Figures 8-13, respectively, where the curves of the average rates and cumulative production were obtained by simply averaging the high and low production data. In Table 5, the CBM water production by coal seam was estimated under the assumptions of initial reservoir conditions and the average data of Figures 8-13. In the case of simultaneous multiple-well production, the well interference and coalbed water recharge will also have an effect on the dewatering rate of coalbeds.

Table 4. Parameter settings of type wells for the major coal seams.

\begin{tabular}{|c|c|c|c|c|c|}
\hline Type Well & Coal Seam & Thickness, $\mathrm{ft}$ & Permeability, md & Porosity, $\%$ & Depth, $\mathrm{ft}$ \\
\hline \hline High & Cook & 25 & 80 & 2 & 350 \\
\hline Low & Cook & 15 & 50 & 2 & 300 \\
\hline High & Wall & 50 & 60 & 2 & 655 \\
\hline Low & Wall & 20 & 42 & 2 & 326 \\
\hline High & Pawnee & 40 & 130 & 2 & 660 \\
\hline Low & Pawnee & 20 & 100 & 2 & 330 \\
\hline High & Knobloch & 65 & 120 & 2 & 680 \\
\hline Low & Knobloch & 20 & 35 & 2 & 330 \\
\hline High & Rosebud-Mckay & 20 & 120 & 2 & 450 \\
\hline Low & Rosebud-Mckay & 15 & 35 & 2 & 350 \\
\hline High & Flowers-Goodale & 20 & 120 & 2 & 700 \\
\hline Low & Flowers-Goodale & 15 & 35 & 2 & 394 \\
\hline
\end{tabular}

Cook Coal - Northern Cheyenne

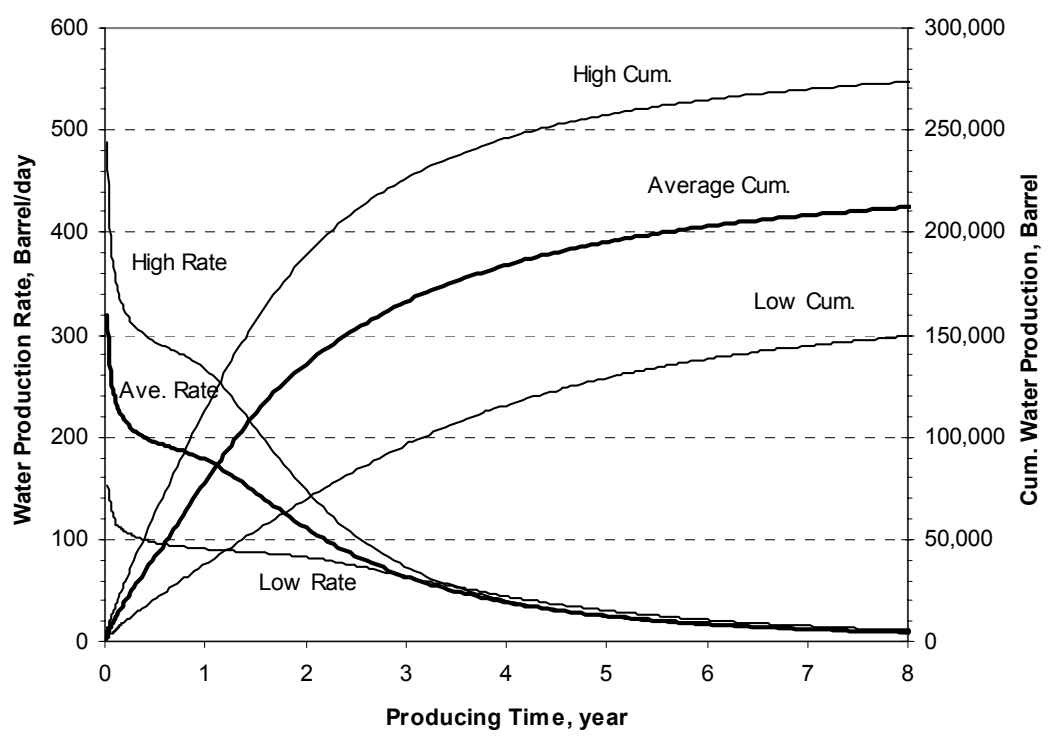

Figure 8. Simulated water productions of high, low, and average type wells for the Cook coal seam. 
Wall Coal - Northern Cheyenne

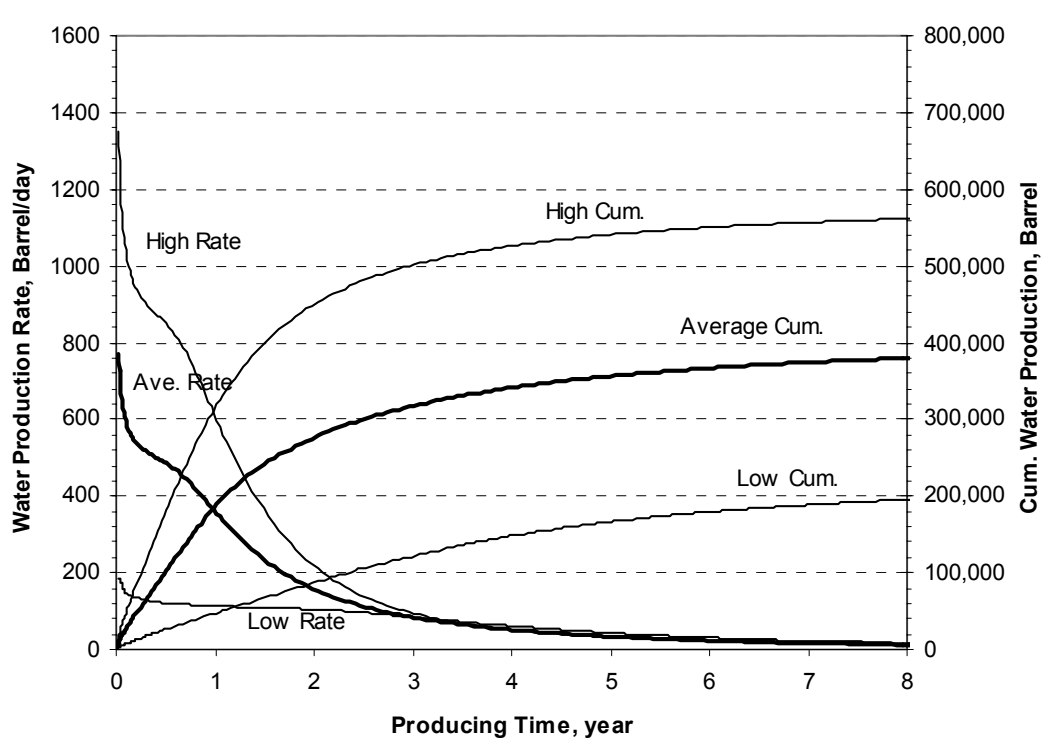

Figure 9. Simulated water productions of high, low, and average type wells for the Wall coal seam.

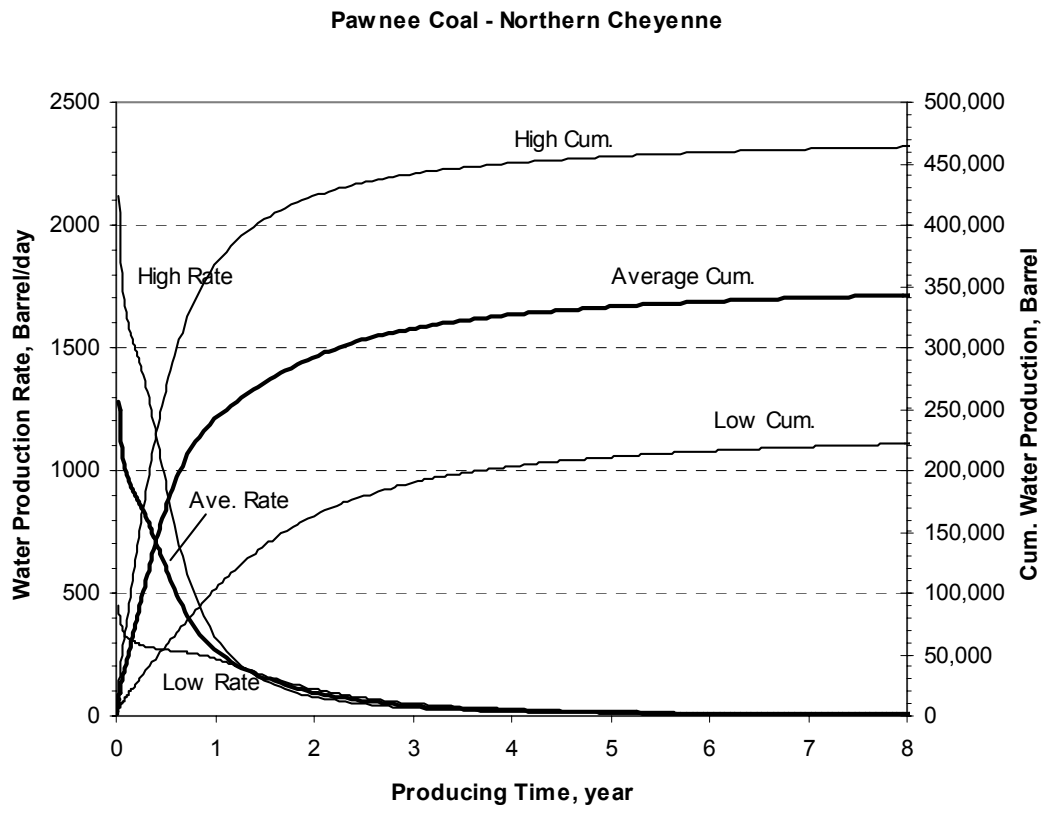

Figure 10. Simulated water productions of high, low, and average type wells for the Pawnee coal seam. 
Knobloch Coal - Northern Cheyenne

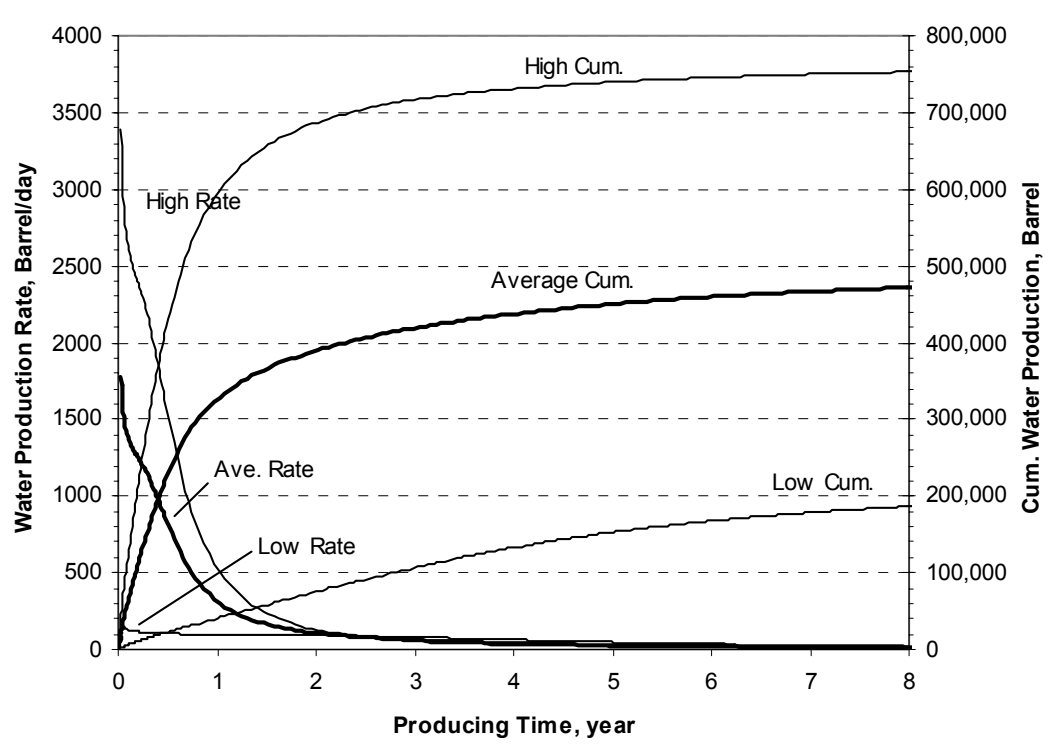

Figure 11. Simulated water productions of high, low, and average type wells for the Knobloch coal seam.

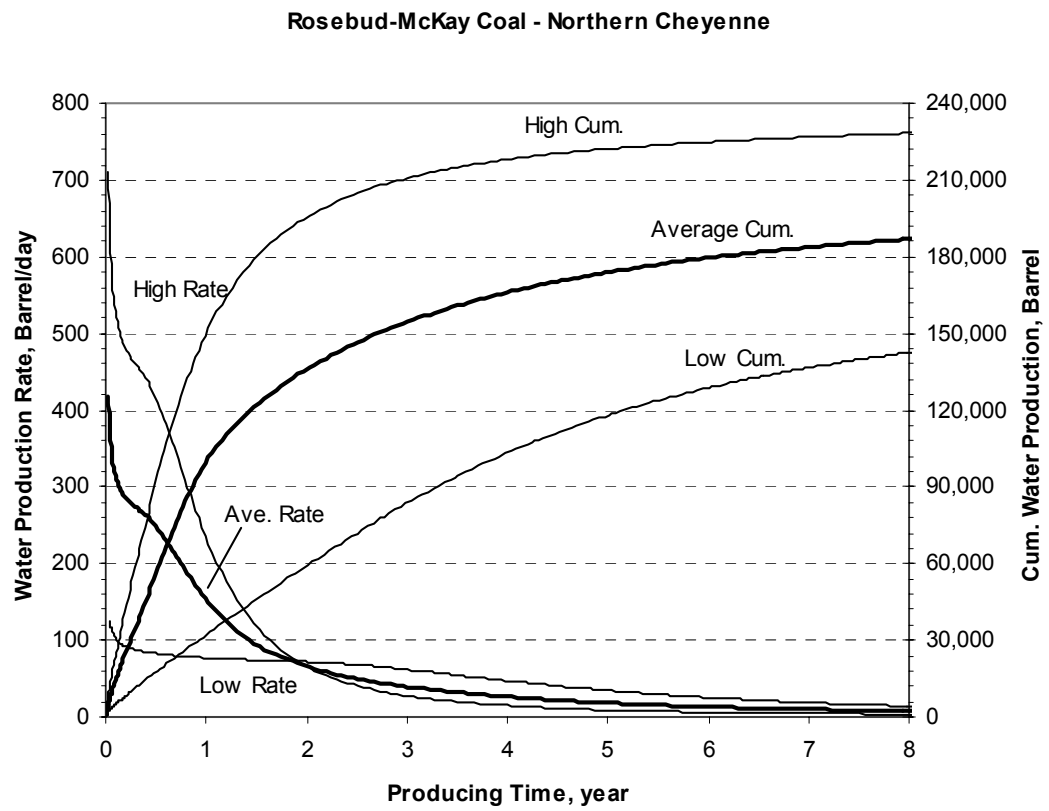

Figure 12. Simulated water productions of high, low, and average type wells for the Rosebud-Mckay coal seam. 
Flowers-Goodale Coal - Northern Cheyenne

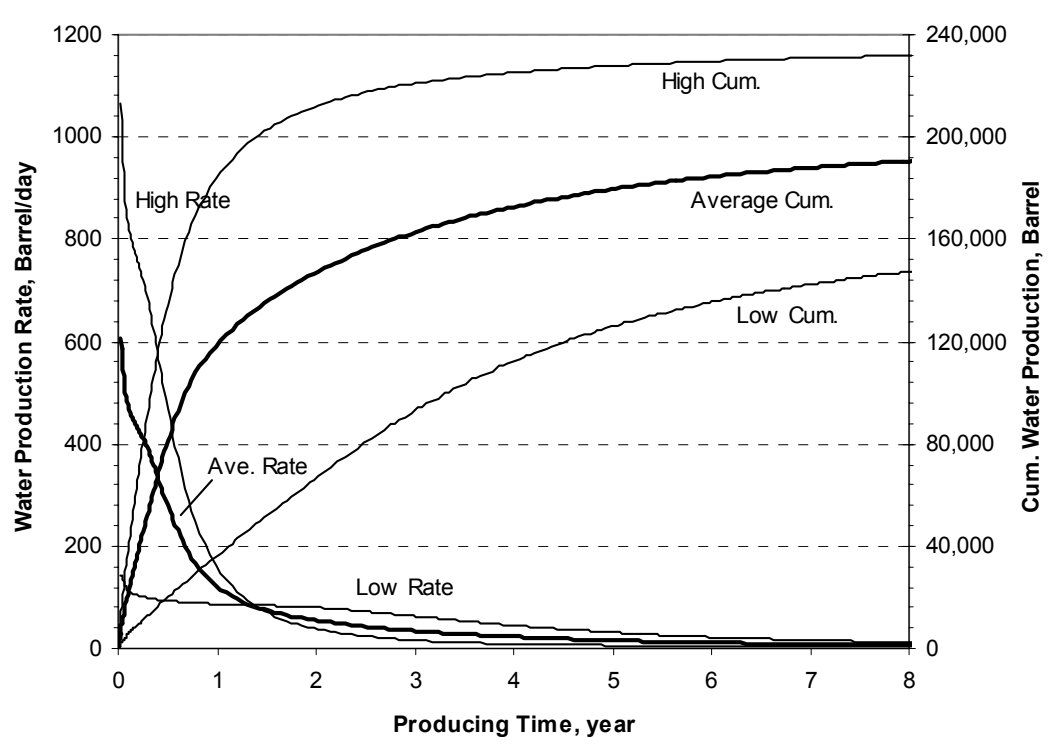

Figure 13. Simulated water productions of high, low, and average type wells for the Flowers-Goodale coal seam.

Table 5. Estimated CBM water productions by coal seams.

\begin{tabular}{|c|c|c|c|c|}
\hline Coal Seam & $\begin{array}{c}\text { Total Acres with } \\
\text { Thickness }>20 \mathrm{ft}, \\
\text { acres }\end{array}$ & $\begin{array}{c}\text { Max Potential } \\
\text { Producing } \\
\text { Wells }\end{array}$ & $\begin{array}{c}\text { Peak Water } \\
\text { Production Rate } \\
\text { per Well, } \\
\text { gpm }\end{array}$ & $\begin{array}{c}\text { Eight-year Cum. Water } \\
\text { Production per Well, } \\
\text { Million Barrels }\end{array}$ \\
\hline \hline Cook & 7,680 & 48 & 9.3 & 0.212 \\
\hline Wall & 197,120 & 1,232 & 20.4 & 0.56 \\
\hline Pawnee & 138,880 & 868 & 37.9 & 0.34 \\
\hline Brewster-Arnold & $\sim$ & $\sim$ & $\sim$ & $\sim$ \\
\hline Knobloch & 307,840 & 1,924 & 52.5 & 0.47 \\
\hline Flowers-Goodale & & & 17.5 & 0.191 \\
\hline Rosebud-McKay & & & 12.25 & 0.186 \\
\hline Robinson & & & & \\
\hline Terret & & & & \\
\hline
\end{tabular}




\section{Chapter 4: Coalbed Water Characteristics}

The CBM-produced water in the PRB has sodium as a dominant cation and bicarbonate as the major anion, and the concentrations of these constituents appear to increase as well locations move from the eastern part of the basin in Wyoming to the northwestern part of the basin in Montana. Therefore, the quality of coalbed water on the Reservation will largely affect how the produced water can effectively be managed in an environmentally sound manner. The salinity of CBM water commonly refers to its total dissolved solids (TDS), but salinity can be estimated by measuring the electrical conductivity (EC) of water, expressed as decisiemen per meter $(\mathrm{dS} / \mathrm{m})$, or in millimhos per centimeter $(\mathrm{mmhos} / \mathrm{cm})$. The U.S. Department of Agriculture defines water with an EC greater than $3.0 \mathrm{dS} / \mathrm{m}$ as saline. The sodicity of CBM water is another important indicator relating to the abundance of sodium to the abundance of calcium and magnesium, or sodium adsorption ratio (SAR). Usually, SAR values greater than 3.0 may deteriorate soil structure and are considered to be a threat to crops and native plants. The potential impacts and beneficial uses of CBM water are discussed in this chapter based on the new water chemistry data from USGS, data from the neighboring Decker Field and Colstrip area, and the reports from previous researches conducted at the Reservation.

\section{SAR, EC and TDS}

In 1970s, an evaluation of the Tribe's groundwater quality was conducted and later published by HKM in 1983. According to that report, water samples from the coal beds of the Fort Union had adjusted SAR values ranging from 2.6 to 101. In 2002, coalbed water samples were collected by the USGS in the newly drilled wells along the southern boundary of the NCIR from Pawnee, Knobloch, Flowers-Goodale, and Wall coal beds. We received the water chemistry data of six water samples from Mike Cannon of the USGS, Helena, Montana. Table 6 gives the SAR, pH, EC and TDS values of the water samples, which shows consistent high SAR values, ranging from 33 to 66, from different coal beds.

Table 6. SAR, pH, EC and TDS of the six water samples

\begin{tabular}{|c|c|c|c|c|c|c|c|c|c|c|c|}
\hline & $\begin{array}{c}\text { Station Number } \\
\text { (USGS) } \\
\end{array}$ & Date & Well Location & Coal Seam & $\begin{array}{c}\text { Well } \\
\text { Depth, } \\
\mathrm{ft}\end{array}$ & $\begin{array}{c}\text { Water Level } \\
\text { Depth, } \\
\mathrm{ft} \\
\end{array}$ & $\begin{array}{c}\text { Surface } \\
\text { Altitude, } \\
\mathrm{ft} \\
\end{array}$ & $\mathrm{pH}$ & $\begin{array}{c}\mathrm{SC}, \\
\mathrm{uS} / \mathrm{cm} \\
\end{array}$ & SAR & $\begin{array}{l}\text { TDS, } \\
\mathrm{mg} / \mathrm{L} \\
\end{array}$ \\
\hline Sample 1 & 452139106504701 & $5 / 22 / 2003$ & T5S R40E 31 & Wall & 655 & 625.9 & 4440 & 8.3 & 1970 & 61 & 1250 \\
\hline Sample 2 & 452411106301601 & $5 / 20 / 2003$ & T5S R42E 14 & Flowers-Goodale & 394 & 107.46 & 3220 & 8.1 & 1580 & 63 & 1000 \\
\hline Sample 3 & 452416106413001 & $5 / 21 / 2003$ & T5S R41E 17 & Pawnee & 348 & 181.86 & 3740 & 8.2 & 2960 & 39 & 2020 \\
\hline Sample 4 & 452429106435201 & $5 / 22 / 2003$ & T5S R40E 13 & Wall & 326 & 199.89 & 3940 & 8.1 & 2980 & 33 & 2020 \\
\hline Sample 5 & 452355106333701 & $5 / 20 / 2003$ & T5S R42E 16 & Knobloch & 370 & 262.61 & 3400 & 8.3 & 2460 & 64 & 1620 \\
\hline Sample 6 & 452408106382201 & $5 / 21 / 2003$ & T5S R41E 14 & Knobloch & 356 & 238.42 & 3510 & 8.3 & 2580 & 66 & 1720 \\
\hline
\end{tabular}

The depths of the sampled coal beds range from 326 to $655 \mathrm{ft}$ and a general trend indicates an increase in SAR and a decrease in TDS with the coalbed depth, as shown in Table 6 and Figure 14. However, additional data will be needed to verify such a correlation. 


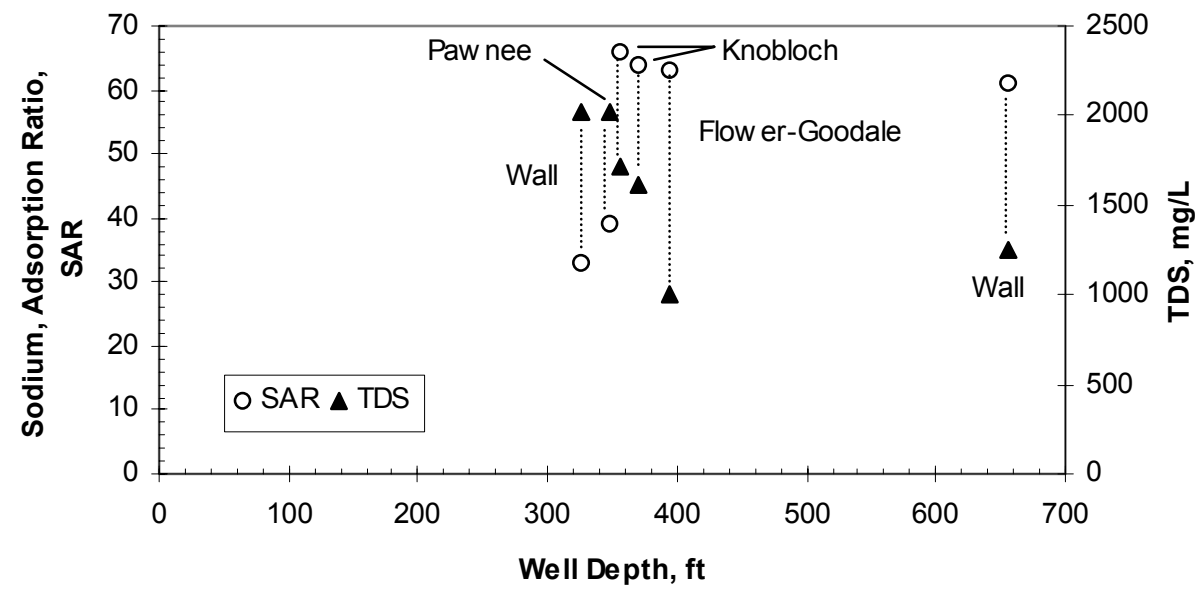

Figure 14. Total Dissolved Solids (TDS) and Sodium Adsoption Ratio (SAR) vs. water sample depth.

Table 7 shows the concentrations of major constituents of the six water samples. In comparison to the average CBM water in the PRB (Table 8), the relatively low concentrations of calcium and magnesium in the water samples result in much higher SAR values than the average SAR value of 25.5 in the PRB. Also notably, sample 3, 4, 5, and 6 have very high sulfate concentrations, ranging from 379 to $766 \mathrm{mg} / \mathrm{L}$, while the average sulfate concentration of CBM water in the PRB is about $4 \mathrm{mg} / \mathrm{L}$. Coinciding with low sulfate concentrations, sample 1 and 2 also have low calcium and magnesium concentrations as plotted in a Schoeller diagram, Fig 15. Formation waters associated with coalbed methane in the PRB have a common chemical character, in which the waters contain primarily sodium and bicarbonate and have very low sulfate/bicarbonate ratios. In a recent paper by Van Voast (2003), the author concluded that regardless of formation lithology or age, the distinct geochemical signature evolves through the processes of biochemical reduction of sulfate, enrichment of bicarbonate, and precipitation of calcium and magnesium. Waters rich in sulfate, calcium, and magnesium occur in many coalbed aquifers but are not found in association with methane.

For comparison, water chemistry data from the adjacent CX CBM field and Colstrip coalmines were downloaded from the web site of the Groundwater Information Center (GWIC) at the Montana Bureau of Mines and Geology (MBMG). The CX Field operated by the Fidelity Exploration and Production Company is located in the Decker area of Montana and is approximately fifteen miles south of the reservation. Methane has been produced from the Anderson (Dietz 1, 2, 3) coalbed in the CX Field. The Colstrip coalmines are about twenty-one miles north of the reservation, where no significant methane was found in the Rosebud, Mckay, or Robison coal formation. We collected 77 and 155 sets of water chemistry data from the CX Field (Anderson coalbed) and the Colstrip coalmines (Rosebud-MckayRobison coal formation), respectively. The water samples were obtained from a depth greater than $200 \mathrm{ft}$ in the CX Field and a depth ranging from 95 to $200 \mathrm{ft}$ in the Colstrip area. In comparison with samples 1 and 2, the average of constituent concentrations from the CX Field data was plotted with that from the Colstrip data in Figure 16. The difference is distinct between the waters associated with and without methane. 
Table 7. Major chemical constituents in the six water samples

\begin{tabular}{|c|c|c|c|c|c|c|c|c|c|}
\hline & $\begin{array}{c}\text { Calcium, } \\
\mathrm{mg} / \mathrm{L}\end{array}$ & $\begin{array}{c}\text { Magnesium, } \\
\mathrm{mg} / \mathrm{L}\end{array}$ & $\begin{array}{c}\text { Potassium, } \\
\mathrm{gm} / \mathrm{L}\end{array}$ & $\begin{array}{c}\text { Sodium, } \\
\mathrm{mg} / \mathrm{L} \\
\end{array}$ & $\begin{array}{c}\text { Alkalinity } \\
\text { (as CaCO3), } \\
\mathrm{mg} / \mathrm{L} \\
\end{array}$ & $\begin{array}{c}\text { Chloride, } \\
\mathrm{mg} / \mathrm{L} \\
\end{array}$ & $\begin{array}{c}\text { Fluoride, } \\
\mathrm{mg} / \mathrm{L} \\
\end{array}$ & $\begin{array}{l}\text { Silica, } \\
\mathrm{mg} / \mathrm{L}\end{array}$ & $\begin{array}{c}\text { Sulfate, } \\
\mathrm{mg} / \mathrm{L}\end{array}$ \\
\hline Sample 1 & 3.34 & 1.54 & 3.59 & 540 & 1100 & 7.12 & 6.3 & 7.02 & 23.9 \\
\hline Sample 2 & 2.35 & 0.703 & 2.64 & 431 & 898 & 6.92 & 6.6 & 9.31 & 4 \\
\hline Sample 3 & 11.2 & 10.4 & 6.16 & 750 & 883 & 10.4 & 9 & 8.47 & 686 \\
\hline Sample 4 & 16.4 & 13.3 & 5.62 & 730 & 760 & 9.66 & 9.6 & 8.48 & 766 \\
\hline Sample 5 & 4.34 & 2.07 & 4.16 & 645 & 935 & 9.91 & 9.4 & 8.35 & 379 \\
\hline Sample 6 & 4.08 & 2.18 & 5.36 & 661 & 654 & 14 & 4.9 & 8.87 & 631 \\
\hline
\end{tabular}

Table 8. Water quality comparison of the NC water samples with the average CBM water in PRB

\begin{tabular}{|l|l|l|}
\hline \multirow{2}{*}{ Constituent } & Average CBM Water in PRB & Water Samples from NC Coal Seams \\
\cline { 2 - 3 } & Concentration & Concentration \\
\hline \hline Sodium & $619 \mathrm{mg} / \mathrm{L}$ & $431-750 \mathrm{mg} / \mathrm{L}$ \\
Potassium & $7 \mathrm{mg} / \mathrm{L}$ & $2.64-6.16 \mathrm{mg} / \mathrm{L}$ \\
Calcium & $25 \mathrm{mg} / \mathrm{L}$ & $2.35-16.4 \mathrm{mg} / \mathrm{L}$ \\
Magnesium & $12 \mathrm{mg} / \mathrm{L}$ & $0.703-13.3 \mathrm{mg} / \mathrm{L}$ \\
Carbonate & $0 \mathrm{mg} / \mathrm{L}$ & \\
Bicarbonate & $1920 \mathrm{mg} / \mathrm{L}$ & $797-1341 \mathrm{mg} / \mathrm{L}$ \\
Chloride & $18 \mathrm{mg} / \mathrm{L}$ & $6.92-14.0 \mathrm{mg} / \mathrm{L}$ \\
Sulfate & $4 \mathrm{mg} / \mathrm{L}$ & $4-766 \mathrm{mg} / \mathrm{L}$ \\
Nitrite + Nitrate as N & $<0.05 \mathrm{mg} / \mathrm{L}$ & \\
Fluoride & $1 \mathrm{mg} / \mathrm{L}$ & $4.9-9.6 \mathrm{mg} / \mathrm{L}$ \\
Total Potassium Hydrocarbons & $<1 \mathrm{mg} / \mathrm{L}$ & \\
Total Dissolved Solids & $1750 \mathrm{mg} / \mathrm{L}$ & $1250-2020 \mathrm{mg} / \mathrm{L}$ \\
Specific Conductance & $2730 \mu \mathrm{mhos} / \mathrm{cm}$ & $1580-2980 \mu \mathrm{mh} / \mathrm{cm}$ \\
pH & $7.5 \mathrm{Std} . \mathrm{units}$ & $8.1-8.3 \mathrm{Std} . \mathrm{units}$ \\
SAR & 25.5 & $33-66$ \\
Alkalinity, as CaCO3 & $1580.0 \mathrm{mg} / \mathrm{L}$ & $654-1100 \mathrm{mg} / \mathrm{L}$ \\
Hardness, as CaCO3 & $6.5 \mathrm{grn} / \mathrm{gal}$ & $9-96 \mathrm{mg} / \mathrm{L}$ \\
Arsenic & $0.05 \mu \mathrm{g} / \mathrm{L}$ & $0.3-42.3 \mu \mathrm{g} / \mathrm{L}$ \\
Barium & $700 \mu \mathrm{L} / \mathrm{L}$ & \\
Iron & $2080 \mu \mathrm{g} / \mathrm{L}$ & $104-392 \mu \mathrm{g} / \mathrm{L}$ \\
Boron & $100 \mu \mathrm{L} / \mathrm{L}$ & $7.9-35.5 \mu \mathrm{g} / \mathrm{L}$ \\
Manganese & $20 \mu \mathrm{g} / \mathrm{L}$ &
\end{tabular}




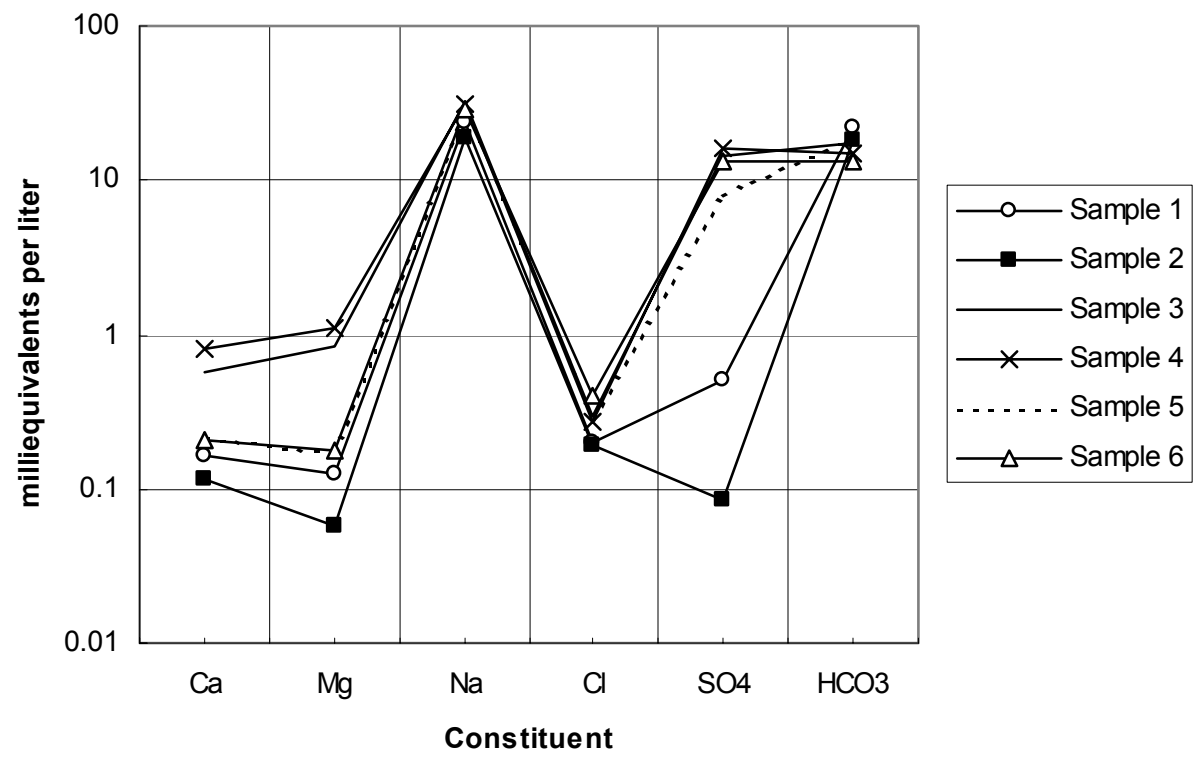

Figure 15. Constituents of CBM-related geochemical signature of the six coalbed water samples.

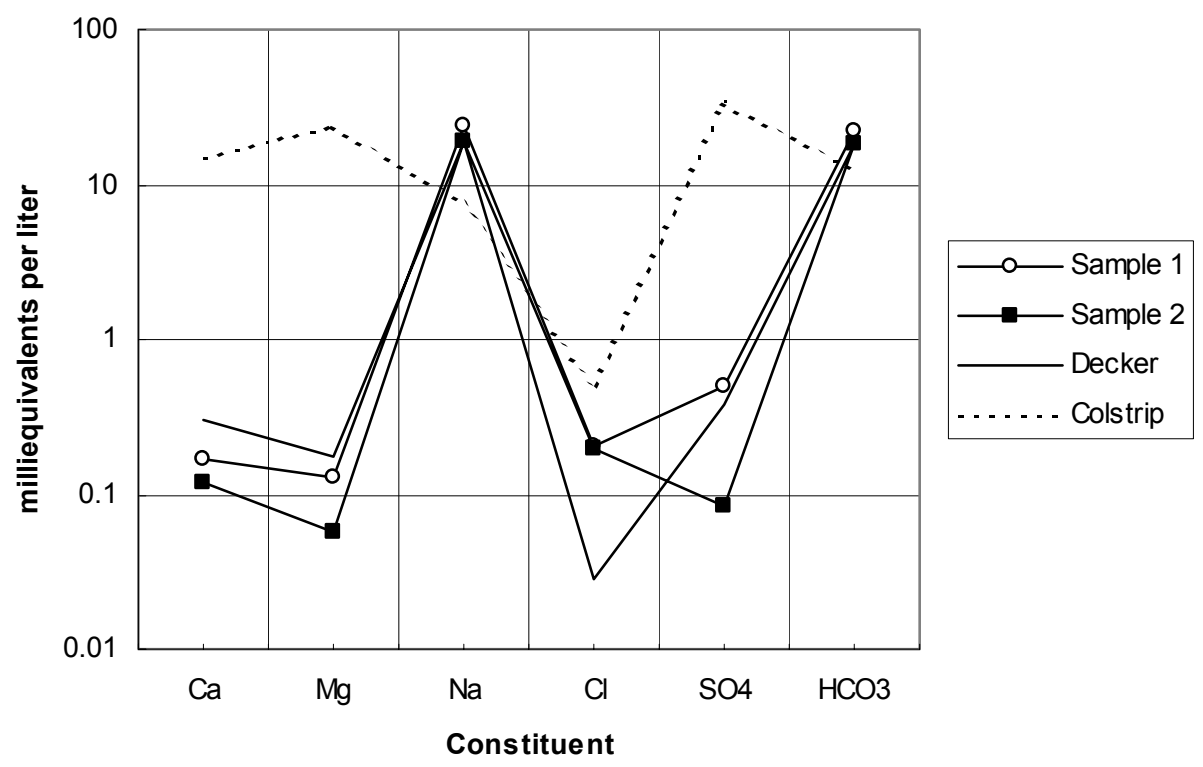

Figure 16. The geochemical signatures of Sample $1 \& 2$ in comparison with the average constituent concentrations of the water samples from the Anderson coalbed in the CX Field and the Rosebud-MckayRobison coal formation in the Colstrip area.

\section{Tribal Draft Surface Water Quality Standards}

The Northern Cheyenne Tribe has submitted a Draft Surface Water Quality Standards of the Tribe to the EPA (Northern Cheyenne Tribe, April 2002) and the draft is in the process of public review. In that draft, numeric criteria for the Sodium Adsorption Ratio (SAR), Electrical Conductivity (EC), and Total Dissolved Solids (TDS) of waters on the Reservation were proposed (Table 9). The Tribe is especially concerned about salinity and its impacts on riparian areas and irrigated lands. Currently, the 
EPA and the State of Montana do not have any numeric criteria for SAR, EC, or TDS because the level tolerated by soils varies greatly based upon soil type. To protect the Tribe's resources, numeric standards will certainly be applied by the Tribe to the quality of CBM water that can be discharged to surface water or to land surface with possible runoff. Because of the very high SAR values, the CBM water on the Reservation will unlikely be permitted for surface discharge by the Tribe unless the water has been treated.

Table 9. Proposed numeric standards for EC, SAR and TDS values applicable to the mainstreams of the Tongue River, Rosebud Creek and their tributaries

\begin{tabular}{|l|c|l|l|}
\hline & $\begin{array}{l}\text { Eletrical } \\
\text { Conductivity } \\
(\mathrm{EC}) \mathrm{dS} / \mathrm{m}\end{array}$ & $\begin{array}{l}\text { Sodium } \\
\text { Adsorption } \\
\text { Ratio (SAR) }\end{array}$ & $\begin{array}{l}\text { Total } \\
\text { Dissolved } \\
\text { Solids (TDS) } \\
\text { mg/L }\end{array}$ \\
\hline Southern Boundary & & & 660 \\
\hline $\begin{array}{l}\text { Irrigation period monthly average, } \\
\text { April 1st - November 15th }\end{array}$ & 1.0 & - & 1320 \\
\hline $\begin{array}{l}\text { Non-irrigation period monthly average, } \\
\text { November 15th -March 31th }\end{array}$ & 2.0 & 2.0 & 1320 \\
\hline Northern Boundary & & & \\
\hline $\begin{array}{l}\text { Irrigation period monthly average, } \\
\text { April 1st - November 15th }\end{array}$ & 1.5 & - & 990 \\
\hline $\begin{array}{l}\text { Non-irrigation period monthly average, } \\
\text { November 15th -March 31th }\end{array}$ & 2.0 & 3.0 & 990 \\
\hline Tributaries & 1.5 & - & 1320 \\
\hline $\begin{array}{l}\text { Irrigation period monthly average, } \\
\text { April 1st - November 15th }\end{array}$ & 2.0 & 3.0 & \\
\hline $\begin{array}{l}\text { Non-irrigation period monthly average, } \\
\text { November 15th -March 31th }\end{array}$ & & & \\
\hline
\end{tabular}

Data Source: The Northern Cheyenne Tribe and Its Reservation, 2002

\section{Potential Impacts and Beneficial Uses}

As with most areas within the arid western United States, the water resources of the Reservation are limited. Precipitation on the Reservation varies from month to month. Mean annual precipitation ranges from 10-14 inches in the lower elevations, to 15-19 inches in the higher elevations. About half of the annual precipitation occurs from April to June (Northern Cheyenne Tribe, 2002). CBM-produced water, as part of the groundwater resources, can be a valuable water source to the Tribe if the water can be used in an environmentally responsible manner.

Potential impacts: In Wyoming, groundwater drawdown has been observed in many CBM development areas. The dewatering of coalbeds may cause water supply problems to the water wells and springs within the same hydraulic system.

The salinity and sodicity are the commonly used indicators to determine if CBM-produced water is suitable for irrigation use or surface discharge. Adapted from the published data (Rhoades, 1977; Oster and Schroer, 1979; and Ayers and Westcot, 1985), Figure 17 shows that the salinity and sodicity levels of the six NCIR CBM-water samples are considerably high. Untreated CBM water might deteriorate soil structure and cause severe reduction in water infiltration rate. The character and distribution of soil materials within the boundaries of the Reservation are consistent with the surrounding region. The soils generally range from loams to clays, but are principally loams to silty clay loams. Because the Tribe's economy is primarily based on cattle production, the predominant agricultural crops on the Reservation are hay, such as grass and alfalfa hay, alfalfa seed and corn for silage and grain (Northern Cheyenne Tribe, 2002). As illustrated in Figure 18, corn and alfalfa are sensitive to saline water. CBM water with a salinity level, measured by EC, between 2 and $3 \mathrm{dS} / \mathrm{m}$ may reduce the corn and alfalfa yields by $10 \%$ to 
$35 \%$, but should not have an effect on grass hay. As the level of salt increases in CBM water, its effect on plant growth increases. Increasing salinity affects growth mainly by reducing the plants ability to absorb water.

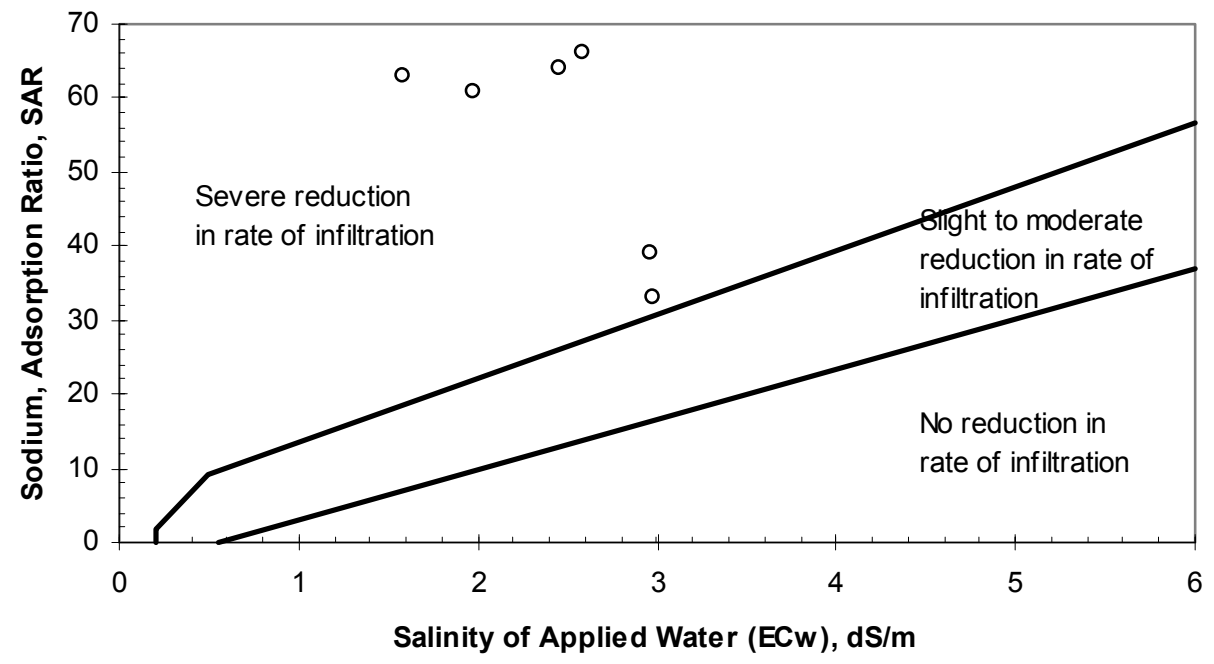

Figure 17. The salinity and SAR values of the six samples in comparison with the potential reduction in rate of water infiltration as affected by salinity and sodium adsorption ratio (adapted from Rhoades, 1977; Oster and Schroer, 1979; and Ayers and Westcot, 1985).

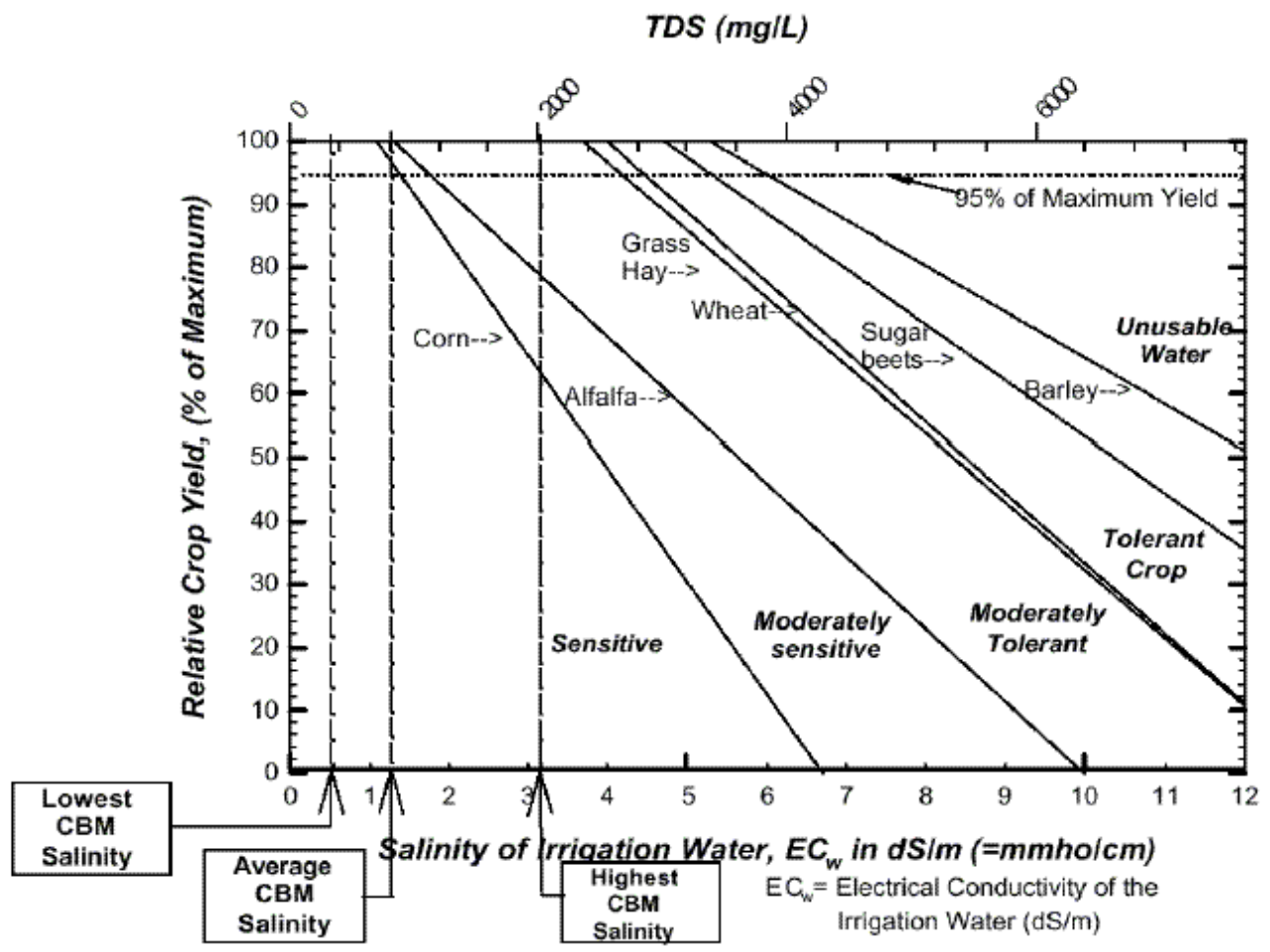

Figure 18. Relationship between relative crop yield and irrigation water salinity for six sample crops (source: Ayers and Westcot, 1985; Arthur et al; 2001). 
The Tribe is very concerned about the impact that CBM-produced water could have on native and culturally significant plants in the Reservation. It is understood that the Tribe considers certain plants to be sacred for their medicinal or traditional values. Warrence, Bauder, and Pearson (2001) have studied the salinity, sodicity and flooding tolerance of selected native plants of the Reservation. Cited from their report, Table 10 provides a summary of sensitivity ratings of the thirty-one plant species found within the Reservation to soil solution salinity $\left(\mathrm{EC}_{\mathrm{e}}\right.$ ), sodium adsorption ratio (SAR), exchangeable sodium percentage (ESP), flooding, and changes in soil pH. The abbreviations used in Table 10 are described in following:

EC

$<2 \mathrm{dS} / \mathrm{m}$

$2-4 \mathrm{dS} / \mathrm{m}$

4-6 dS/m

$>6 \mathrm{dS} / \mathrm{m}$
Salinity Tolerance Rating

Sensitive

Moderately Sensitive

Moderately Tolerant

Tolerant

\author{
Abbreviation \\ $\mathrm{S}$ \\ MS \\ MT \\ $\mathrm{T}$
}

Sodium Tolerance Rating

Extremely sensitive

Very tolerant

\section{Abbreviation \\ ES \\ VT}

The study shows that many of the native plants are salinity sensitive and their acceptable upper limits for SAR are between 1.6 and 8.0. These limits are far below the SAR level of 33-66 measured from the six CBM-water samples. Therefore, the saline-sensitive plants are very likely to be negatively impacted by the flooding of untreated CBM water. 
Table 10. Summary of sensitivity ratings of thirty-one native and culturally significant plant species of the Northern Cheyenne Reservation to soil solution salinity (EC), exchangeable sodium percentage (ESP), flooding, and changes in soil pH.

\begin{tabular}{|c|c|c|c|c|c|c|}
\hline Common Name & Scientific Name & $\begin{array}{c}\text { SALINITY } \\
\text { Rating } \\
\end{array}$ & $\begin{array}{c}\text { SALINITY } \\
\text { Acceptable Upper } \\
\text { Limit ECe (sat) } \\
\text { dS/m } \\
\end{array}$ & $\begin{array}{c}\text { SODIUM } \\
\text { Tolerance } \\
\text { Rating } \\
\end{array}$ & $\begin{array}{c}\text { Flooding Rating Limits, } \\
\text { Inundation } \\
\end{array}$ & $\mathrm{pH}$ range \\
\hline $\begin{array}{l}\text { 1. June Servie } \\
\text { Berry }\end{array}$ & $\begin{array}{l}\text { Amelanchier } \\
\text { alnifolia }\end{array}$ & S & 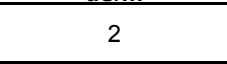 & $\begin{array}{l}\text { ES; ESP 2-10, } \\
\text { SAR 1.6-8.0 }\end{array}$ & MT short term, 2 weeks & no data \\
\hline $\begin{array}{l}\text { 2. Red Osier } \\
\text { Dogwood }\end{array}$ & $\begin{array}{l}\text { Cornus } \\
\text { stolinifera }\end{array}$ & $\mathrm{S}$ & 2 & no data available & MT short term, 2 weeks & $6.5-7.9$ \\
\hline $\begin{array}{l}\text { 3. Common } \\
\text { spikerush }\end{array}$ & $\begin{array}{l}\text { Eleocharis } \\
\text { palustris }\end{array}$ & MS & 4 & no data available & $\begin{array}{l}\text { T long term, } 1 \text { year -; not tolerant } \\
\text { to permanent flooding }\end{array}$ & 4.8-7.9 \\
\hline 4. Horsetail, Field & \begin{tabular}{|l} 
Equisetum \\
arvense
\end{tabular} & MS & 4 & no data available & $\begin{array}{l}\text { T long term, } 1 \text { year }-; \text { not tolerant } \\
\text { to permanent flooding }\end{array}$ & $4.8-7.2$ \\
\hline $\begin{array}{l}\text { 5. Wild } \\
\text { licorice/American }\end{array}$ & $\begin{array}{l}\text { Glycyrrhiza } \\
\text { lepidota }\end{array}$ & MT & 6 & $\begin{array}{l}\text { VT; ESP } 60, \text { SAR } \\
48\end{array}$ & $\begin{array}{l}\text { T long term, } 1 \text { year }-; \text { not tolerant } \\
\text { to permanent flooding }\end{array}$ & $4.8-7.2$ \\
\hline $\begin{array}{l}\text { 6. Goose Berry, red } \\
\text { shoot }\end{array}$ & Ribes setosum & $\mathrm{S}$ & 2 & $\begin{array}{l}\text { ES; ESP 2-10, } \\
\text { SAR 1.6-8.0 }\end{array}$ & $\begin{array}{l}\text { T long term, } 1 \text { year }-; \text { not tolerant } \\
\text { to permanent flooding }\end{array}$ & 4.8-7.9 \\
\hline \begin{tabular}{|l|} 
7. Mint/Field \\
\end{tabular} & Mentha arvensis & S/MS & 2 & $\begin{array}{l}\text { ES; ESP 2-10, } \\
\text { SAR 1.6-8.0 }\end{array}$ & no data available & $4.8-7.9$ \\
\hline $\begin{array}{l}\text { 8. Horsemint/W. } \\
\text { Bergamot }\end{array}$ & $\begin{array}{l}\text { Monarda } \\
\text { fistulosa }\end{array}$ & MS & 4 & no data available & no data available & $5.5-7.9$ \\
\hline \begin{tabular}{|l|} 
9. Water \\
Plant/Water Cress
\end{tabular} & $\begin{array}{l}\text { Nasturium } \\
\text { officinale }\end{array}$ & MS & 4 & no data available & $\begin{array}{l}\text { T long term, } 1 \text { year -; not tolerant } \\
\text { to permanent flooding }\end{array}$ & $4.8-7.2$ \\
\hline 10. Sweet Medicine & \begin{tabular}{|l} 
Oxtropis \\
lamnbertii
\end{tabular} & MS & 4 & no data available & no data available & $5.5-7.9$ \\
\hline 11. Chokecherry & Prunus virginiana & S & 2 & $\begin{array}{l}\text { ES; ESP 2-10, } \\
\text { SAR 1.6-8.0 }\end{array}$ & I very short term; $<2$ weeks & 4.8-7.9 \\
\hline $\begin{array}{l}\text { 12. Cottonwood, G. } \\
\text { Plains }\end{array}$ & $\begin{array}{l}\text { Populus } \\
\text { deltoides }\end{array}$ & MS & 4 & no data available & $\begin{array}{l}\text { T long term, } 1 \text { year }-; \text { not tolerant } \\
\text { to permanent flooding }\end{array}$ & $4.8-7.9$ \\
\hline 13. Box Elder & Acer negundo & MT & 6 & no data available & $\begin{array}{l}\text { T long term, } 1 \text { year -; not tolerant } \\
\text { to permanent flooding }\end{array}$ & 4.8-7.9 \\
\hline 14. Green ash & $\begin{array}{l}\text { Fraxinus } \\
\text { pennsylvania }\end{array}$ & MT & 6 & no data available & $\begin{array}{l}\text { T long term, } 1 \text { year }-; \text { not tolerant } \\
\text { to permanent flooding }\end{array}$ & $6.5-7.9$ \\
\hline 15. Sand bar willow & Salix exigua & MS & 4 & no data available & $\begin{array}{l}\text { T long term, } 1 \text { year -; not tolerant } \\
\text { to permanent flooding }\end{array}$ & $4.8-7.9$ \\
\hline 16. Snow Berry & \begin{tabular}{|l} 
Symphoricarpos \\
occidentalis
\end{tabular} & MS & 4 & \begin{tabular}{|l|} 
ES; ESP 2-10, \\
SAR 1.6-1.8 \\
\end{tabular} & $\begin{array}{l}\text { T long term, } 1 \text { year -; not tolerant } \\
\text { to permanent flooding }\end{array}$ & 4.8-7.9 \\
\hline 17. Cattail & Typha latifolia & MS & 4 & no data available & $\begin{array}{l}\text { T long term, } 1 \text { year }+; \text { not tolerant } \\
\text { to permanent flooding }\end{array}$ & $4.8-7.9$ \\
\hline 18. Wild Plum & $\begin{array}{l}\text { Prunus } \\
\text { americana }\end{array}$ & $S$ & 2 & $\begin{array}{l}\text { ES; ESP 2-10, } \\
\text { SAR 1.6-1.8 }\end{array}$ & $\begin{array}{l}\text { T long term, } 1 \text { year }+; \text { not tolerant } \\
\text { to permanent flooding }\end{array}$ & no data \\
\hline 19. Sweet grass & \begin{tabular}{|l} 
Hierochloe \\
odorata
\end{tabular} & MS & 4 & no data available & no data available & $4.8-7.2$ \\
\hline 20. Quaking aspen & \begin{tabular}{|l|} 
Populus \\
tremuloides
\end{tabular} & S & 2 & no data available & $\begin{array}{l}\text { T long term, } 1 \text { year }+; \text { not tolerant } \\
\text { to permanent flooding }\end{array}$ & no data \\
\hline $\begin{array}{l}\text { 21. Saw beak } \\
\text { sedge }\end{array}$ & Carex stipata & MS & 4 & no data available & T long term, 1 year & $5.0-7.9$ \\
\hline 22. Leafy aster & Aster foliactus & $S$ & 2 & no data available & $\begin{array}{l}\text { T long term, } 1 \text { year }+; \text { not tolerant } \\
\text { to permanent flooding }\end{array}$ & $4.8-7.2$ \\
\hline 23. Stinging nettle & Urtica dioica & MS & 2 & no data available & I very short term, $<2$ weeks & $4.8-7.2$ \\
\hline 24. Bulrush & \begin{tabular}{|l|} 
Scirpus \\
nevadensis
\end{tabular} & $\mathrm{MT} / \mathrm{T}$ & 6 & no data available & $\begin{array}{l}\text { T long term, } 1 \text { year }+; \text { not tolerant } \\
\text { to permanent flooding }\end{array}$ & $4.8-7.9$ \\
\hline 25. Arrow leaf & Sagittaria latifolia & MS & 4 & no data available & $\begin{array}{l}\text { T long term, } 1 \text { year }+; \text { not tolerant } \\
\text { to permanent flooding }\end{array}$ & 4.8-7.9 \\
\hline 26. Golden currant & Ribes aureum & MS & 4 & $\begin{array}{l}\text { ES; ESP 2-10, } \\
\text { SAR 1.6-8.0 }\end{array}$ & no available data & 4.8-7.9 \\
\hline $\begin{array}{l}\text { 27. Skunkbush } \\
\text { sumae }\end{array}$ & Rhus trixobata & MT & 6 & no data available & MT short term, 2 weeks & $6.5-7.9$ \\
\hline \begin{tabular}{|l|}
$\begin{array}{l}\text { 28. Milkweed, } \\
\text { showy }\end{array}$ \\
\end{tabular} & $\begin{array}{l}\text { Asclepias } \\
\text { speciosa }\end{array}$ & MS & 4 & no data available & I very short term, $<2$ weeks & $4.8-7.2$ \\
\hline 29. Western yarrow & $\begin{array}{l}\text { Achillea } \\
\text { millelolium }\end{array}$ & MS & 4 & no data available & I very short term, $<2$ weeks & $4.8-7.9$ \\
\hline 30. Raspberry red & Rubes idaue & $S$ & 2 & $\begin{array}{l}\text { ES; ESP 2-10, } \\
\text { SAR 1.6-8.0 }\end{array}$ & no data available & $4.8-7.9$ \\
\hline 31. Rose Bush & Rosa arkansa & MS & 4 & no data available & MT short term, 2 weeks & $4.8-7.9$ \\
\hline
\end{tabular}

Source: Warrence, Bauder and Pearson, 2001. 
Potential beneficial uses: There are currently about 1,800 acres of irrigated land on the Reservation. In addition, 10,700 to 21,160 acres are considered as irrigable land by means of gravity or sprinkler systems. Treated CBM water can provide a large quantity of water for irrigation if it can be done economically. Untreated CBM water can directly be used for livestock watering and many non-agricultural uses, including domestic, commercial, and municipal uses. The CBM water will also be a valuable water source for future industrial uses of the Reservation. The anticipated industrial developments may include coal mine, coal-fired power plant, coal liquefaction plant, and coal gasification plant. The current and anticipated water uses are summarized in Table 11.

Table 11. Northern Cheyenne current and anticipated water uses.

\begin{tabular}{|l|l|l|l|}
\hline \multicolumn{1}{|c|}{ Type of Water Use } & Unite Size & Current Consumption & $\begin{array}{c}\text { Anticipated Future } \\
\text { Consumption } \\
\text { (acre-feet/vr) }\end{array}$ \\
\hline \hline Agricultural Use & & & \\
\hline Irrigation & 1,794 acres of irrigated land & $>2,242$ & \\
\hline Potential Irrigation & $\begin{array}{l}10,710-21,160 \text { acres of } \\
\text { irrigable land by means of } \\
\text { gravity or sprinkler systems }\end{array}$ & & $>24,975$ \\
\hline $\begin{array}{l}\text { Stock Watering, including water } \\
\text { losses due to evaporation and } \\
\text { seepage from pounds }\end{array}$ & 9,678 animal units and 12 & 986 & \\
\hline Non-Agricultural Use & gallons per day per head & & \\
\hline Domestic Use & & & \\
\hline Commercial Use & $\sim 5000$ tribal residents & 651 (or 0.581 MGD) & \\
\hline Municipal Use & $\begin{array}{l}\text { Mostly located in the town of } \\
\text { Lame Deer }\end{array}$ & 175 (or 0.1565 MGD) & \\
\hline $\begin{array}{l}\text { The combined average non- } \\
\text { agricultural water use, including } \\
\text { water losses due to line leakage } \\
\text { and water slippage }\end{array}$ & Public areas, community areas & 45 (or 0.0402 MGD) & \\
\hline $\begin{array}{l}\text { Anticipated Industrial Use } \\
\text { Coal Mine }\end{array}$ & and government buildings & & 9,100 \\
\hline Coal Fired Power Plant & 10 million tons/year & & 6,000 \\
\hline Coal Liquefaction & 500 Mega Watt & & $640-1,050$ \\
\hline Coal Gasification & 250 mmscf & & \\
\hline Coal Slurry Pipeline & 10 million tons/year & & \\
\hline
\end{tabular}

Data Source: The Northern Cheyenne Tribe and Its Reservation, 2002 


\section{Chapter 5: Economics of Alternative Water Handling Options}

As a result of the current expansion of CBM development in the United States, a considerable number of research papers and reports have been published on $\mathrm{CBM}$ water related issues. A recent report by ALL Consulting (2003) provided a comprehensive overview of the treatment technologies for CBMproduced water and its potential beneficial uses. New technologies are being tested to deal with the problem of disposal of CBM water. However, the local policies and economics that drive the choices of applicable technologies are different in practically every situation. With regard to the Northern Cheyenne Reservation, there are four basic options for dealing with CMB produced water: (1) surface discharge with water treatment; (2) direct use without treatment; (3) re-inject the water into formations below the Lebo Member formation, i.e. deeper injection; or (4) re-inject the water into the channel sandstone units above the Lebo Member formation, i.e. shallow injection. It is very likely that any surface discharged CMB water on the Reservation will be required to meet the Tribe's Draft Surface Water Quality Standards. The economics of these options are discussed in this chapter. The descriptions of treatment methods as well as their cost and price data are largely cited from published reports.

\section{Surface Discharge and Water Treatment}

As discussed in Chapter 4, CBM water underlying the Reservation is in general unsuitable for irrigation because of its high SAR value. Surface discharge of untreated CBM water may cause adverse effects on local soil and native plants. However, the water quality is sufficient for domestic and livestock uses as well as for other anticipated industrial and economic uses. Under the Tribe's present economic circumstance, domestic and livestock uses could only consume a small portion of the potentially large volume of produced CBM water. In comparison to direct uses without treatment, treating CBM water for surface discharge or use can be much more expensive in terms of the initial capital costs for facility installation as well as the operation and maintenance (O\&M) costs.

\section{Use of CBM water without treatment:}

The capital costs of using CBM water for a domestic water supply or livestock watering system are mainly associated with the installation of pumps, pipes, and water storage tanks, which is usually within several thousand dollars. The O\&M costs might vary between 2 and 6 cents per barrel depending on actual operations (ALL Consulting, 2003; Advanced Resources International, 2002). For example, CBM water across limestone rocks (rip rap) can help precipitate out dissolved iron before filling to water tanks. These rocks can then be replaced, eliminating any permanent staining of the surrounding landscape. This method was used by Pennaco Energy at the Tietjen Ranch in the PRB near Gillette, Wyoming (EPA, 2001).

\section{Surface discharge with treatment:}

Surface discharge with water treatment requires installing a water treatment system, surface discharging the treated water, and either trucking or deep re-injecting the residual concentrate. Many treatment technologies exist or are being tested for removing the excessive ions, metals and organics in CBM water. Cited from the report by ALL Consulting (2003), Table 12 lists the current used or tested treatment technologies and their effectiveness on reducing certain constituents in CBM water. To comply with the Tribe's Draft Surface Water Quality Standards, CBM water must be treated to reduce the high SAR value before the water can be discharged to surface water or to land surface with possible runoff. As listed in Table 12, effective methods for SAR reduction include Reverse Osmosis (RO), Ion Exchange (IE), Capacitive Desalination (CD), and Electrodialysis Reversal (EDR). The detailed processes of these methods can be found in many publications, such as the Handbook on CBM Produced Water by ALL Consulting (2003) and the report by Hodgson (2002).

The initial capital cost for a sizable treatment system using any of these technologies is generally very high. For example, a RO-based system with a 900 -gpm (30,860 barrel per day for a 96-well unit) water treating capacity could cost about $\$ 3,380,000$ by deep re-injecting the residual concentrate or $\$ 1,880,000$ by trucking the residual concentrate to disposal (Advanced Resources International, 2002). 
Reverse osmosis is a synthetic membrane process that removes most dissolved solids, resulting in a clean water stream and a concentrated waste stream. The residual concentrate must be further processed by deep re-injecting or trucking to other disposal sites. The actual operating costs of water treatment for SAR reduction might vary between 4.5 and 40 cents per barrel, as estimated in Table 12 .

Table 12. Treatment technologies and their effectiveness on reducing certain constituent types present in CBM produced water

\begin{tabular}{|c|c|c|c|c|c|c|c|c|c|c|c|}
\hline Treatment Technology & $\begin{array}{l}\text { Heavy } \\
\text { Metals }\end{array}$ & SAR & TDS & $\mathrm{Ba}$ & $\mathrm{Fe}$ & EC & Organics & $\mathrm{Na}$ & $\mathrm{HCO} 3$ & Bio & $\begin{array}{l}\text { Estimated Cost } \\
\text { (cents per barrel) }\end{array}$ \\
\hline $\begin{array}{l}\text { Freeze-Thaw/Evaporation } \\
\text { (FTE) }\end{array}$ & $\sqrt{ }$ & & $\sqrt{ }$ & $\sqrt{ }$ & $\sqrt{ }$ & $\sqrt{ }$ & & $\sqrt{ }$ & & & 30.4 \\
\hline Reverse Osmosis (RO) & $\sqrt{ }$ & $\sqrt{2}$ & $\sqrt{ }$ & $\sqrt{ }$ & $\sqrt{ }$ & $\sqrt{ }$ & & $\sqrt{ }$ & $\sqrt{1}$ & & 16.4 \\
\hline Ultraviolet Light & & & & & & & $\sqrt{\beta}$ & & & $\sqrt{ }$ & \\
\hline Chemical Treatment & & & & & & & & & & $\sqrt{ }$ & \\
\hline Ion Exchange & $\sqrt{ }$ & $\sqrt{2}$ & & $\sqrt{ }$ & $\sqrt{ }$ & $\sqrt{ }$ & & $\sqrt{ }$ & $\sqrt{1}$ & & $4.5-6.6$ \\
\hline $\begin{array}{l}\text { Capacitive Desalination } \\
\text { (CD) }\end{array}$ & $\sqrt{ }$ & $\sqrt{2}$ & & $\sqrt{ }$ & $\sqrt{ }$ & $\sqrt{ }$ & & $\sqrt{ }$ & $\sqrt{ }^{1}$ & & 10 \\
\hline $\begin{array}{l}\text { Electrodialysis Reversal } \\
\text { (EDR) }\end{array}$ & $\sqrt{ }$ & $\sqrt{2}$ & & $\sqrt{ }$ & $\sqrt{ }$ & $\sqrt{ }$ & & $\sqrt{ }$ & $\sqrt{1}$ & & $27-40$ \\
\hline Distillation & $\sqrt{ }$ & & $\sqrt{ }$ & $\sqrt{ }$ & $\sqrt{ }$ & $\sqrt{ }$ & $\sqrt{3}$ & $\sqrt{ }$ & & $\sqrt{ }$ & $10-19$ \\
\hline Artificial Wetlands & $\sqrt{ }$ & & $\sqrt{ }$ & $\sqrt{ }$ & $\sqrt{ }$ & $\sqrt{ }$ & & & & $\sqrt{ }$ & $1-2$ \\
\hline
\end{tabular}

Source: ALL Consulting, 2003.

$\sqrt{ }$ - indicates treatment process can reduce constituent type.

$1-\mathrm{pH}$ adjustment would be required prior to treatment

2 - water adjustment by addition of calcium and magnesium would be required.

3 - limited to certain organics based on volatility, boiling point, chemical composition, etc.

\section{Injection into Formations below the Lebo Member}

There are several permeable zones below the Lebo Member of the Fort Union Formation that may be suitable injection zones, including the Lance and Fox Hills formations. In other areas of the PRB, Wyoming DEQ has issued general permits for more than 250 Class $\mathrm{V}$ wells to be used to inject into the Fox Hills, Lance, Wasatch, and Fort Union Formations (ALL Consulting, 2003). The drilling and completion costs of a typical deep-injection well for water disposal in the PRB are estimated at \$35,200 (Advanced Resources International, 2002). As well depth increases, well drilling and completion costs rise to account for the extra costs with increased depth. Deeper injection zones also mean higher pump equipment and operating costs. While the injection of CBM-produced water into formations below the Lebo Member avoids surface discharge impacts in the same manner as injection into the shallow channel sandstones, it does not preserve the CBM water that has relatively better quality than the water in deeper formations below the Lebo Member.

\section{Injection into Shallow Sandstone Units}

The stacked sequences of paleo-channels above the Lebo Member are considered as good candidates for CBM water disposal by injection. From bottom to top, the channel sandstones are informally named A-F, in which the A unit is the basal sandstone in the Tongue River Member. An assessment of the water intake and storage capacities of these channel sandstones is provided in Chapter 6. Sand units are structurally deeper at the southern border and shallower at the north border of the Reservation, where the sand units D and above are exposed near the northern border. The B, C, and D units are extensive in the Reservation area, which range mostly from $200 \mathrm{ft}$ to $900 \mathrm{ft}$ in depth. The drilling and completion costs for a water disposal well completed in that depth interval are estimated around $\$ 15,150$ (Advanced Resources International, 2002). In comparison to deeper formations below the Lebo shale, shallow channel sandstones could mean that gravity flow can be utilized to dump water from a holding tank to a down-gradient disposal well. More importantly, the injection into the channel 
sandstones can not only preserve the produced CBM water but also 'recycle' the water back to the aquifers within the same hydraulic system as that of the coal seams.

\section{Summary}

Based on the available data and assessments of the cited reports, the capital and O\&M costs for the identified CBM water handling options identified were estimated (Table 13). Although various treatment technologies for SAR reduction are being tested in the PRB, most of them have not been proven to be economical. Surface discharge will probably not be economically beneficial for the Reservation if discharged CBM water is required to meet the Tribe's Draft Surface Water Quality Standards. Deeper injections into formations below the Lebo Member are apparently more expensive than shallow injections into the channel sandstones. More importantly, the valuable resource of CBM water could be degraded by deeper injections. Therefore, the best option for the Tribe might be a combination of shallow injections with some of the produced water being directly used for domestic water supply and livestock watering.

\begin{tabular}{|l|l|l|}
\hline \multirow{2}{*}{ Water Disposal } & \multicolumn{2}{|c|}{ Water Disposal Costs } \\
\cline { 2 - 3 } & Capital Costs/Well or Unit & O\&M Costs/Bbl. \\
\hline \hline Direct Domestic and Livestock Uses & $\$ 1,400-5,000$ & $\$ 0.02-0.06$ \\
\hline Surface Discharge with Treatment & $>\$ 400,000$ (treating system only) & $\$ 0.10-0.16$ \\
\hline Injection into Channel Sandstone Units & $\$ 15,150$ & $\$ 0.06$ \\
\hline Injection into Deep Formations & $\$ 35,200$ & $\$ 0.14$ \\
\hline
\end{tabular}

Table 13. Estimated capital costs for alternative water disposal methods. 


\section{Chapter 6: Injection of CBM Water into Channel Sandstone Units}

As summarized in Chapter 5, the injection of CBM water into shallow sandstone units is regarded as the preferred method for the disposal of large quantity of CBM water. Isopach maps of the sand units have been created, which can be used to assess their storage capacities. The water injectivity of a well is determined by the surrounding sand properties and the well configuration. Presented in this chapter, a simplified chart was created to estimate the injectivity, as a function of the sand thickness and permeability, for the channel sandstone units underlying the Reservation.

\section{Distribution of Channel Sandstone Units}

Among the identified channel sandstone units, Units B-F, from bottom to top, are considered as good candidates for water disposal by injection. Figure 19 and 20 show the gross and net isopach maps of the B sandstone unit, respectively. The isopach maps of C, D, E, and F sandstone units are given in Figure $21-24$, respectively. The D unit is of the best in terms of overall sand thickness and areal extent. The isopach maps were used to interpret the drainage patterns of these stacked channels (Figure 7). The coincidence of the traces of the channels through time implies that there may have been paleo-structural control on their locations. 


\section{B Sand (Gross) Isopach Map}

Northern Cheyenne Indian Reservation, Big Horn and Rosebud Counties, Montana
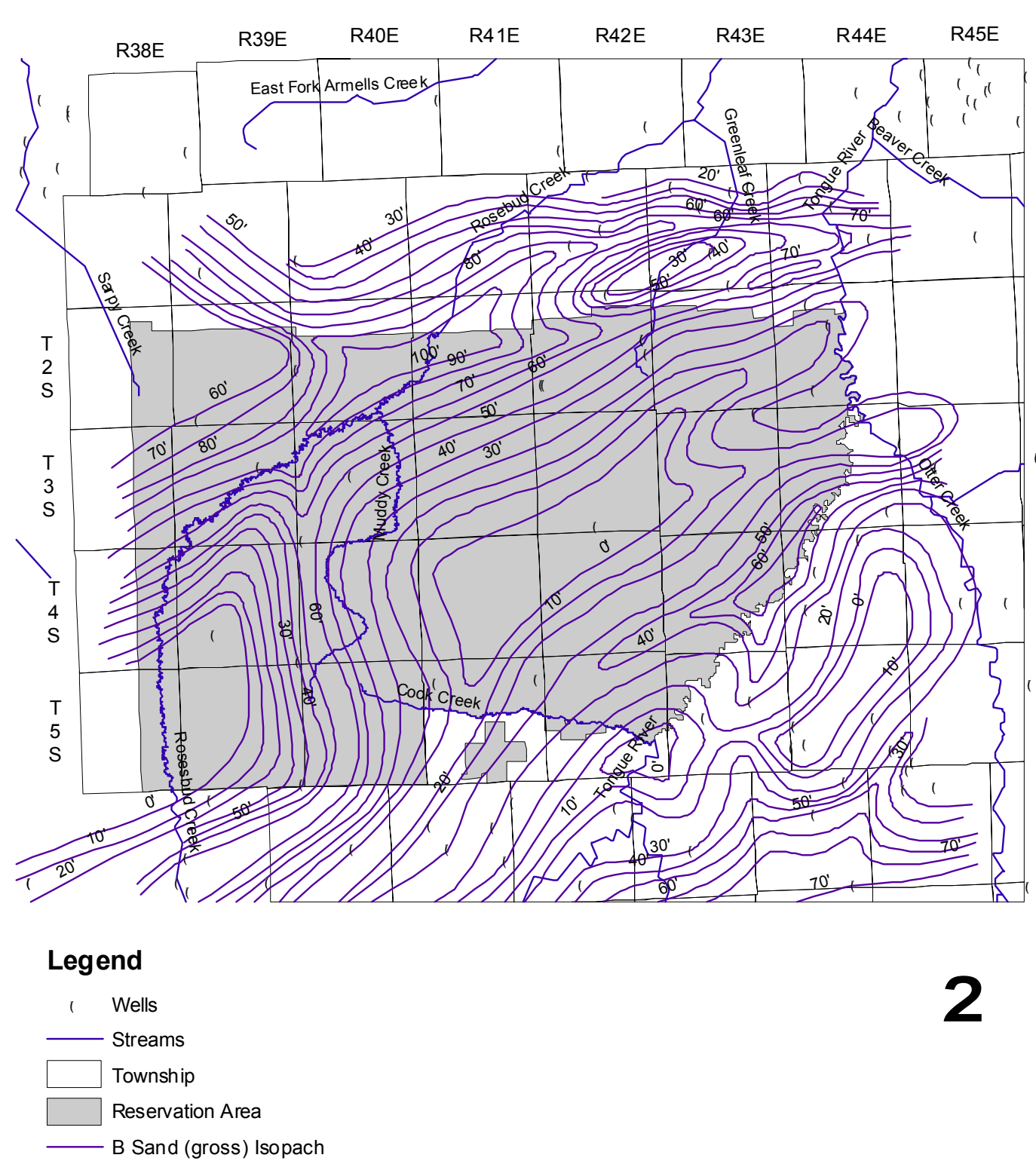

2

Figure 19. Isopach map of the gross interval of the B sandstone unit. 


\section{B Sand (Net) Isopach Map}

Northern Cheyenne Indian Reservation, Big Horn and Rosebud Counties, Montana
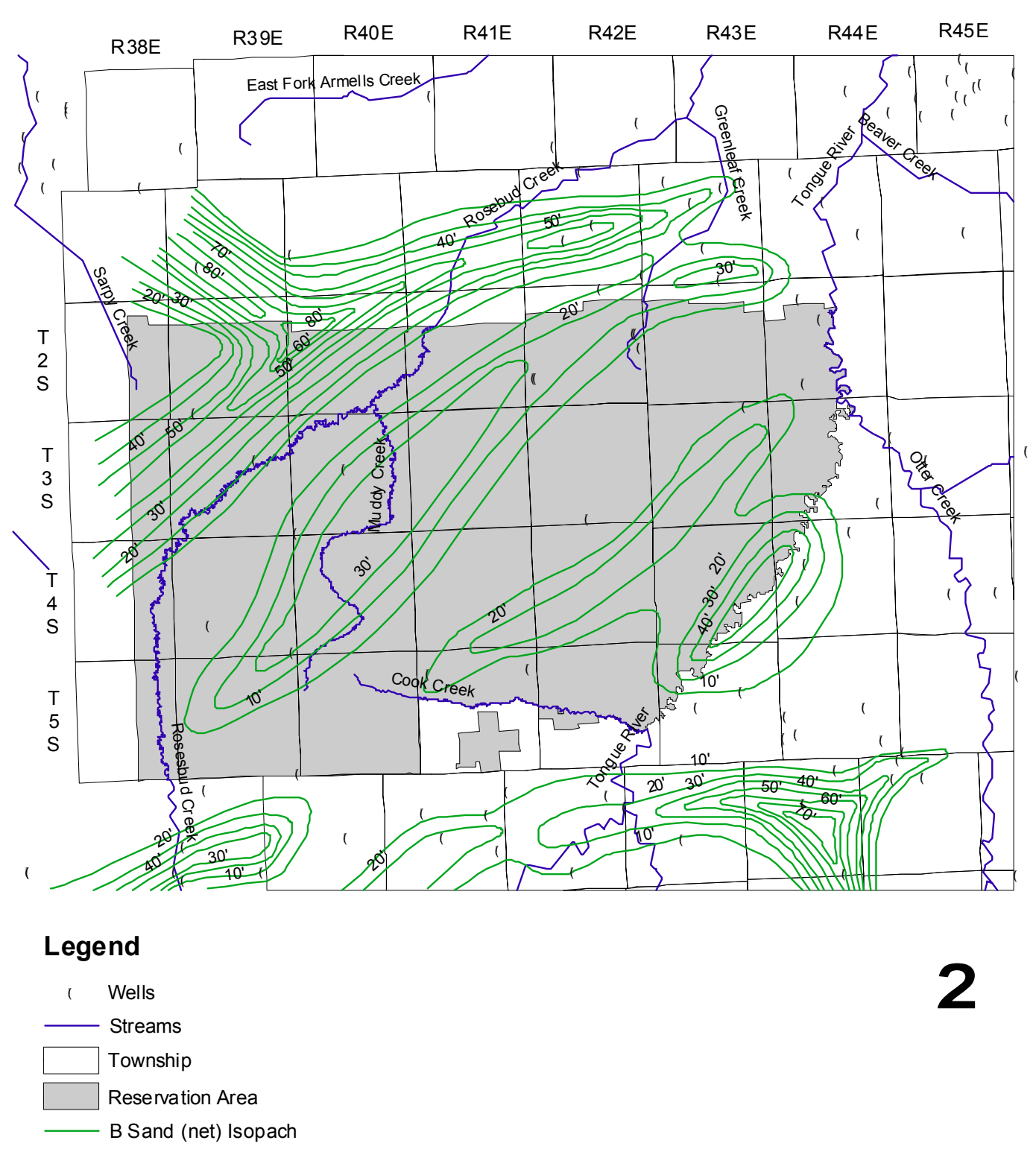

Figure 20. Isopach map of the net thickness of the B sandstone unit. 


\section{Sand Isopach Map}

Northern Cheyenne Indian Reservation, Big Horn and Rosebud Counties, Montana
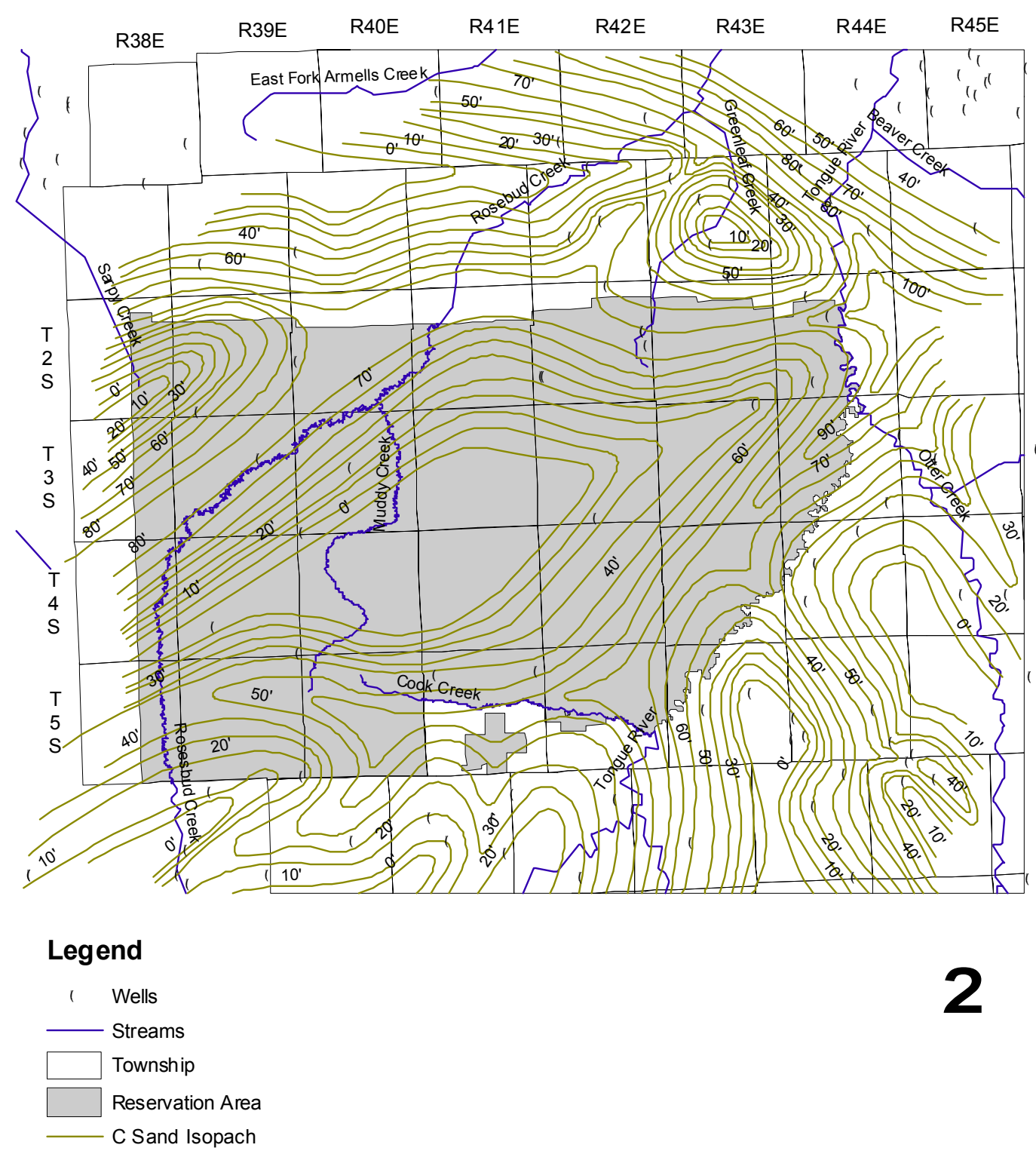

Figure 21. Isopach map of the $\mathrm{C}$ sandstone unit. 


\section{Sand Isopach Map}

Northern Cheyenne Indian Reservation, Big Horn and Rosebud Counties, Montana

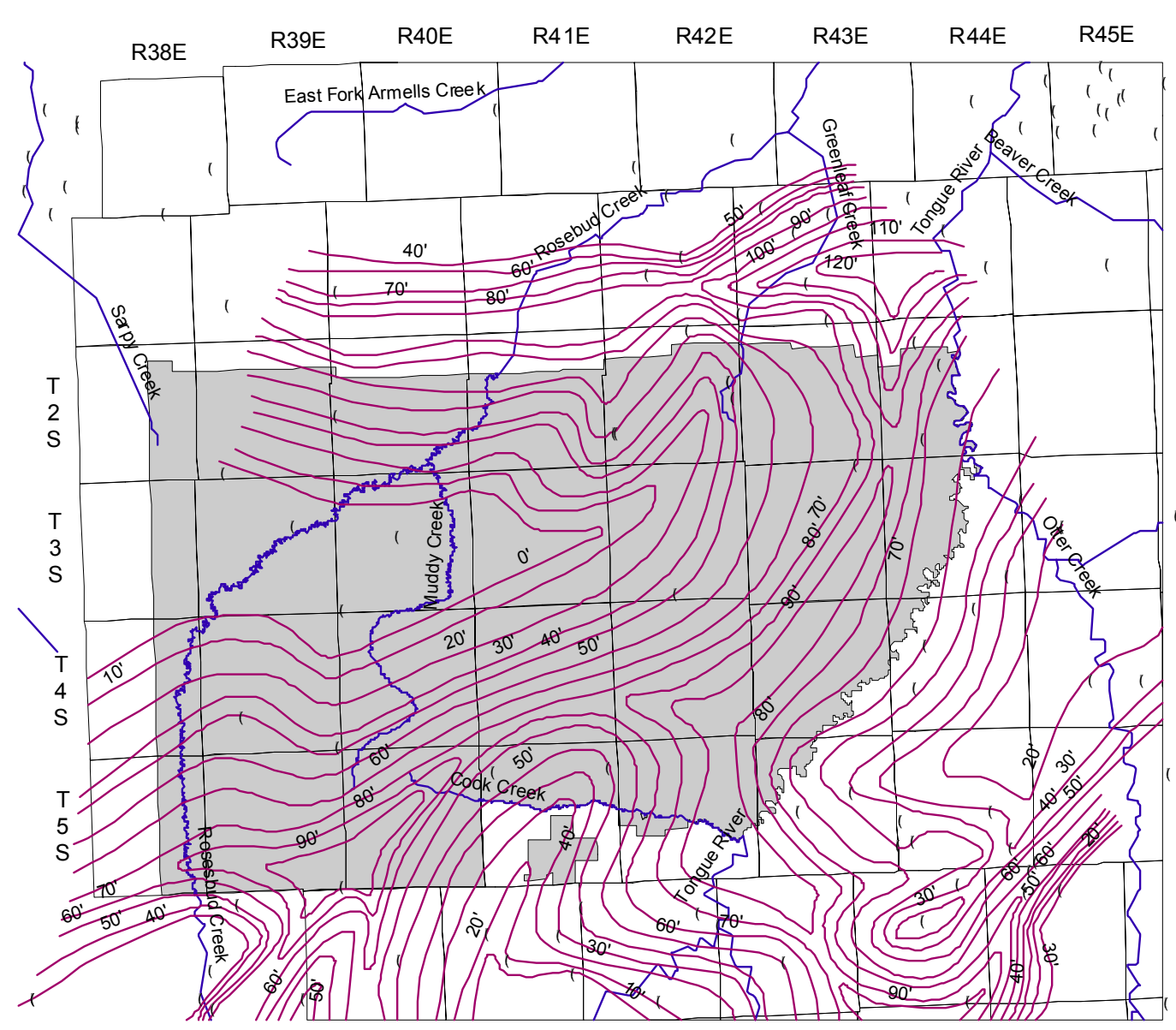

\section{Legend}

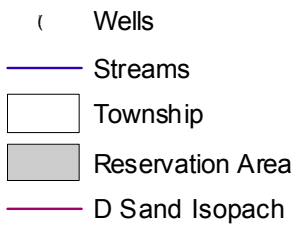

Figure 22. Isopach map of the D sandstone unit. 


\section{E Sand Isopach Map}

Northern Cheyenne Indian Reservation, Big Horn and Rosebud Counties, Montana
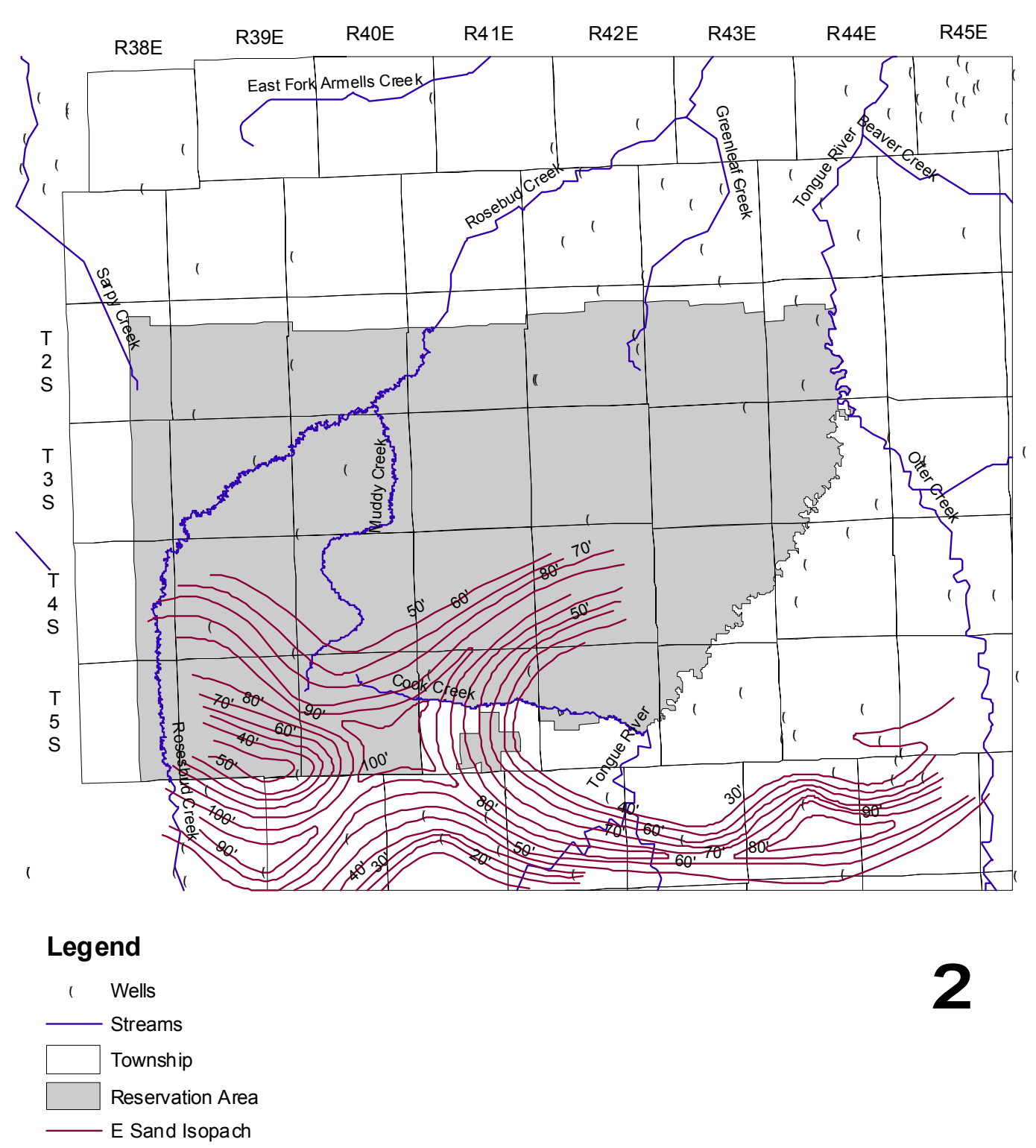

Figure 23. Isopach map of the E sandstone unit. 


\section{F Sand Isopach Map}

Northern Cheyenne Indian Reservation, Big Horn and Rosebud Counties, Montana

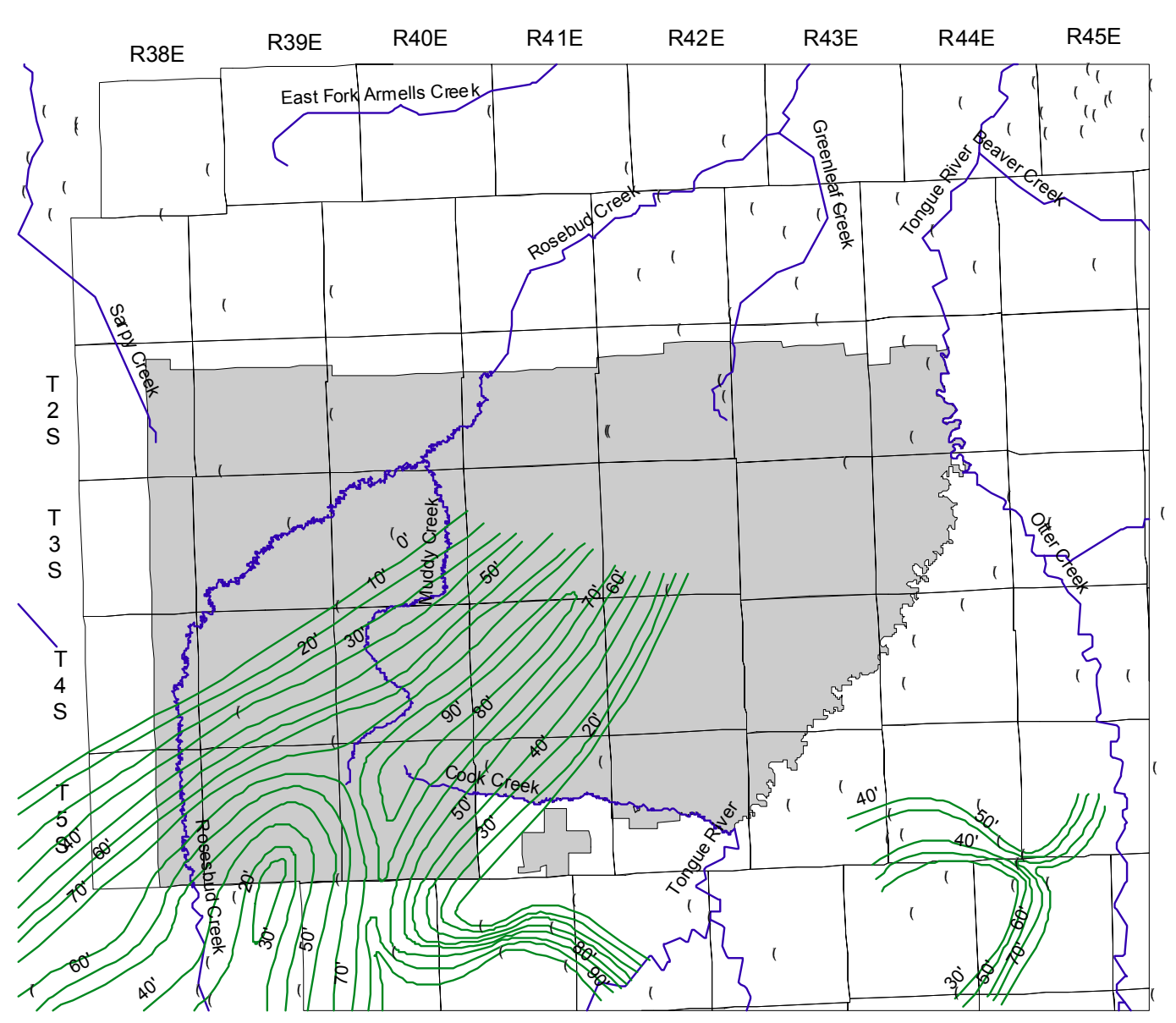

\section{Legend}

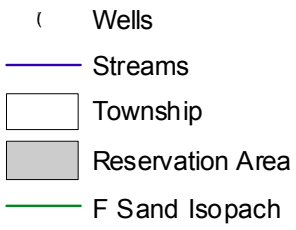

2

Figure 24. Isopach map of the F sandstone unit.

\section{Water Quality Compatibility}

The quality of water within the channel sandstones is believed to be compatible with the CBM water, but has not been confirmed by lab analysis. The scope of this project does not include a detailed investigation of the compatibility of water chemistry between the CBM water and the water in the channel 
sandstone units. In December 2002, we proposed for additional funds to drill a few wells and sample the water in the sand units. However, the proposal for the water compatibility study was not funded.

\section{Porosity and Permeability}

Well log data indicate that porosity in the channel sandstones is as great as $30 \%$. Permeability appears to be good, but needs to be determined by lab analysis. Two outcrop samples of the " $D$ " sand, Sample L-6 and L-7, were collected by Dr. Lopez near the north border of the Northern Cheyenne Reservation. The samples were mailed to the INEEL for further analysis. Core plugs were drilled from the outcrop samples. The porosity and permeability of the cores were measured by Dr. Xina Xie at the INEEL. The diameter of the core drill bit is 1 inch. Rock material L-7 was in irregular shape and was very loosely consolidated, the usable core length was only about 1". Rock material L-6 was well consolidated and a regular core was cut. Tap water was used for the core cutting.

Porosity measurement: The weight method was used to measure the porosity of the cores. The cores were vacuumed and saturated with groundwater. The porosity was calculated from the weight difference before and after the saturation of the groundwater (Eq. 1). The total dissolved solids in the groundwater used for the measurement is $410 \mathrm{ppm}$. The groundwater composition is given in Table 14. The labmeasured porosity is 0.27 on core L-6 and is 0.33 on core L-7, which is consistent with estimated porosity from well log data.

$$
\text { porosity }=\frac{1}{\text { totalcorevolume }} \frac{\text { saturated core weight }- \text { dry core weight }}{\text { groundwaterdensity }}
$$

Table 14. Composition of the groundwater used in measuring porosity.

\begin{tabular}{|l|l|l|l|l|l|l|}
\hline Chemical Constituent & $\mathrm{KNO}_{3}$ & $\mathrm{MgSO}_{4}$ & $\mathrm{CaCl}_{2}$ & $\mathrm{NaNO}_{3}$ & $\mathrm{NaHCO}_{3}$ & $\mathrm{KHCO}_{3}$ \\
\hline Concentration, $\mathrm{g} / \mathrm{L}$ & 0.004 & 0.11 & 0.194 & 0.0034 & 0.0924 & 0.0062 \\
\hline
\end{tabular}

Permeability measurement: After the porosity measurement, the cores were dried at $105^{\circ} \mathrm{C}$ and cooled in a desiccator. The cores were then coated with epoxy resin, and fittings were installed at both ends. $\mathrm{CO}_{2}$ gas was used to measure the gas permeability. The water permeability can be estimated at 0.6 of the average gas permeability. The equation used to calculate the gas permeability is given in Eq. 2. The permeabilities of core L-6 and L-7 were measured as $286 \mathrm{md}$ and $1062 \mathrm{md}$, respectively. The high permeability of core L-7 is due to its loosely consolidated structure. The measured properties of the cores are summarized in Table 15.

$$
\text { gas perm }=\frac{\text { flow rate } \times \text { gas vis cos ity } \times \text { core length } \times \text { atmospheric pressure }}{\text { core cross sec tion area } \times\left(\text { pressure drop }{ }^{2}+2 \times \text { pressure drop } \times \text { atmospheric pressure }\right)}
$$

Table 15. Measured properties of the two cores

\begin{tabular}{|l|l|l|l|l|l|}
\hline Core \# & Dry weight, g & Diameter, cm & Length, cm & Porosity, \% & $\begin{array}{l}\text { Water } \\
\text { permeability, } \\
\text { md }\end{array}$ \\
\hline L-6 & 40.36 & 2.54 & 4.25 & 26.87 & 286 \\
\hline L-7 & 22.38 & 2.46 & 2.78 & 33.17 & 1062 \\
\hline
\end{tabular}




\section{Channel Sandstone Injectibility}

The water intake capability of the channel sandstone units is assessed by their injectivity indexes, defined by Eq. 3. The model, used to estimate injectivity indexes, is based on the well-known singlephase Radial Flow model of Eq. 4 (Peaceman, 1977). The variables in Eqs. 3 and 4 are described in following.

Injectivity Index $\left(I_{w}\right)$ is defined as the injection rate $(q)$ divided by the difference between the injection pressure or well flowing pressure $\left(P_{w f}\right)$ and the reservoir pressure $\left(P_{r}\right)$. Injectivity Index is used as a measure of the ability of the well and injection interval to take up injection fluids.

$$
I_{w}=\frac{q}{P_{w f}-P_{r}}
$$

The basic equation for calculating the Injectivity Index is the single-phase Radial Flow model, expressed as

$$
I_{w}=\frac{q}{P_{w f}-P_{r}}=\frac{0.00708 k h}{B_{w} \mu_{w} \ln \left(r_{e} / r_{w}\right)}
$$

where $k(\mathrm{md})$ is the effective permeability of sand; $h(\mathrm{ft})$ is sand thickness; $\mu_{w}$ is the viscosity of the injected water, $B_{w}$ is water FVF, and $r_{w}$ is the effective radius of the well. The pressure radius, $r_{e}$, depends on the cumulative volume of water, $W_{i}$, that has been injected. $r_{e}$ can be estimated by

$$
r_{e}=\left(\frac{5.61 W_{i}}{\pi h \phi}\right)^{1 / 2}
$$

Stated in terms of the bottom hole pressure (BHP) and producing-block pressure $\left(\mathrm{P}_{\text {block}}\right)$, Peaceman's version of well inflow rate and pressure is

$$
I_{w}=\frac{q}{P_{w f}-P_{\text {block }}}=\frac{0.00708 k h}{B_{w} \mu_{w}\left[\ln \left(r_{e q} / r_{w}\right)+s+c\right]}
$$

where $r_{e q}$ is the equivalent radius ( $\mathrm{ft}$ ) and $s$ is a dimensionless skin factor, incorporating well damage or stimulation, perforation effects, inclined wellbore, and partial penetration effects. For isotropic permeability and square block, Peaceman showed that where the equivalent radius, $r_{e q}$, is about $0.2 \Delta \mathrm{x}$, where $\Delta \mathrm{x}$ is the length of the block edge. The dimensionless coefficient $c$ is determined by flow state and flow pattern. $c$ is set to zero for steady-state flow and -0.5 for pseudosteady-state flow (Mattax, 1990).

If the surface injection pressure, $P_{i}$, is known, the well bottom flowing pressure can be estimated from the expression for a static-fluid column.

$$
P_{w f}=P_{i}+\frac{D \rho}{144}
$$

where $D(\mathrm{ft})$ is the depth of well and $\rho$ is the injected water density in $1 \mathrm{bm} / \mathrm{cf}$.

Estimated injectivity: For the sand units underlying the Reservation, assumptions of 160-acre pattern, steady-state flow, and a fractured wellbore were used in the estimation of the water injectivity. The effect of fractured wellbore was incorporated by a skin factor of -4 . The results are presented in Figure 25, in 
which the injectivity index can be estimated by sand thickness and permeability. Because of the uneven distribution of channel sandstones, the injectivity within a same sand unit could change largely from one location to another, as indicated in Table 16. The top injectivities of unit B, C, and D were estimated at 25,67 , and 75 barrel/day-psi, respectively. It is feasible that large quantity of CBM water can be injected and preserved in these sand units. Taking the $\mathrm{D}$ unit as an example, its initial average injectivity is about $41 \mathrm{barrel} /$ day-psi according to Table 16. If water is injected at a pressure of $100 \mathrm{psi}$ above the formation pressure, 4100 barrels of water could then be injected daily by one injection well.

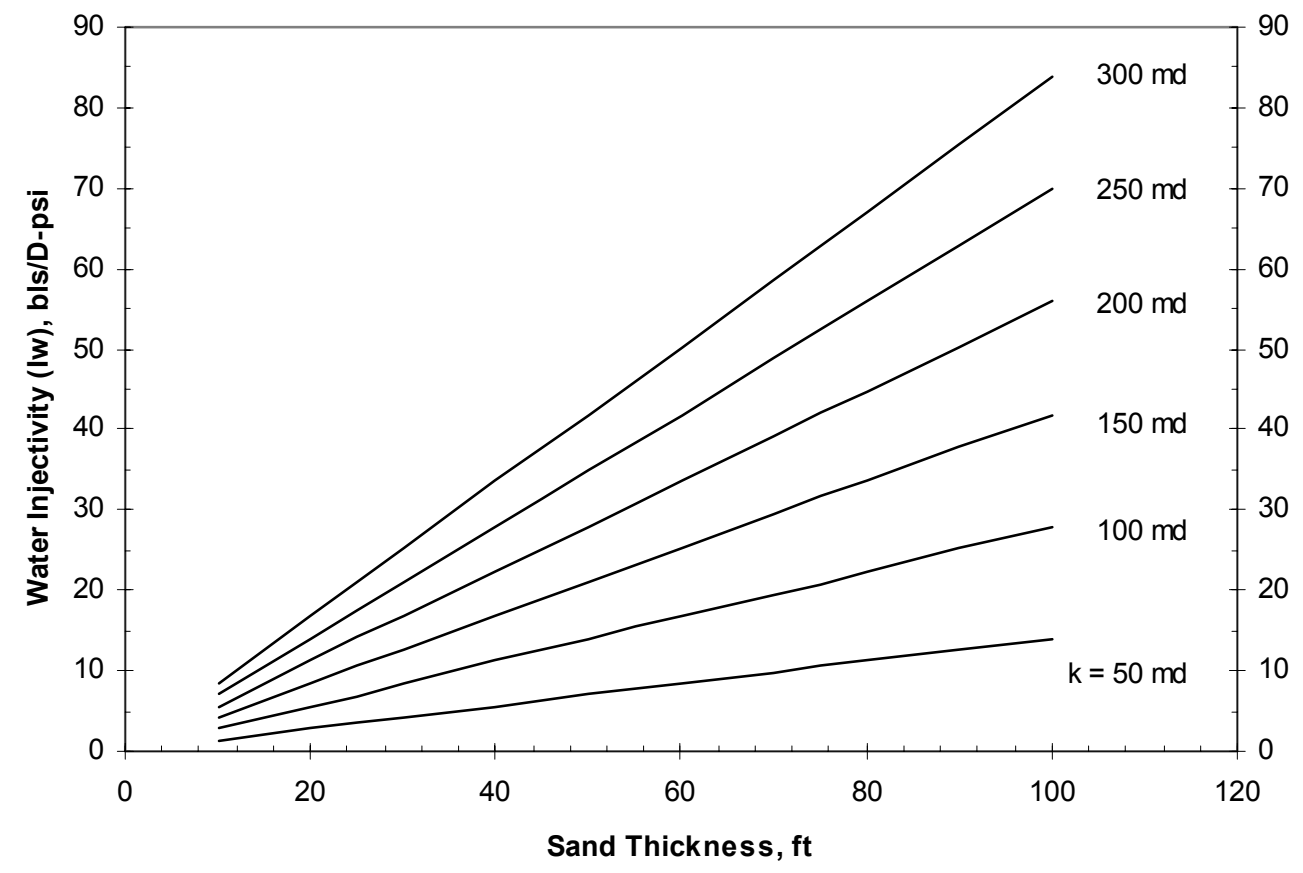

Figure 25. Estimated injectivity as a function of sand thickness and permeability.

Table 16. Initial water intake capabilities of the sand units.

\begin{tabular}{|c|c|c|c|c|c|c|}
\hline Sand & Thickness, & $\begin{array}{c}\text { Depth at } \\
\text { North Edge, } \\
\mathrm{ft}\end{array}$ & $\begin{array}{c}\text { Depth at } \\
\text { South Edge, } \\
\mathrm{ft}\end{array}$ & Total Acres, & Formation Pressure, & Initial Injectivity, \\
acre & $\mathrm{psi}$ & barrel/day-psi \\
\hline \hline $\mathrm{D}$ & $10-90$ & 0 & 700 & 328,800 & $14.7-350$ & $7-75$ \\
\hline $\mathrm{C}$ & $10-80$ & 200 & 900 & 351,840 & $100-450$ & $5.5-67$ \\
\hline $\mathrm{B}$ & $10-30$ & 250 & 950 & 207,360 & $125-475$ & $4-25$ \\
\hline $\mathrm{A}$ & $\sim$ & 300 & 1000 & $\sim$ & $150-500$ & $\sim$ \\
\hline
\end{tabular}

During the injection of water, the Hall plot can be a useful data representation for assessing the injection performance (Figure 26). The Hall plot shows pressure multiplied by duration of injection versus the injected volume. A straight line is expected for constant injectivity and a curving upwards indicates loss of transmissivity that usually occurs over the lifetime of the project. Unwanted fracture propagation can be seen when the plot levels off (International Association of Oil \& Gas Producers, 2000). 


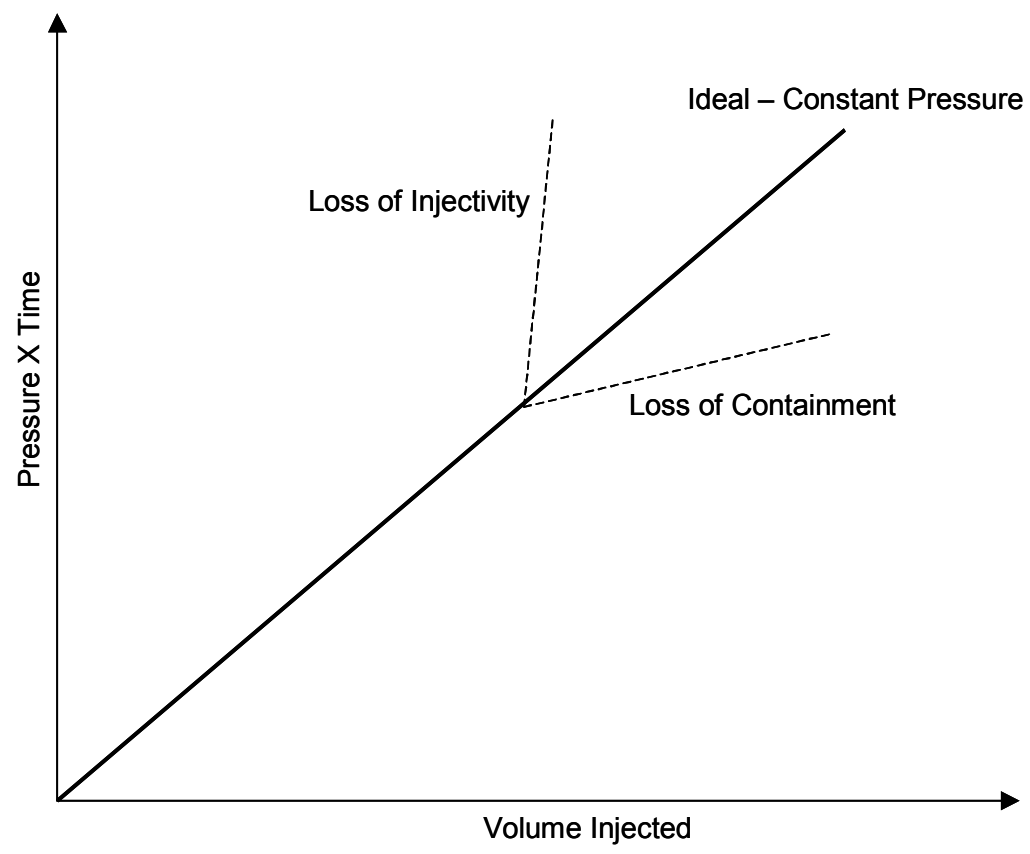

Figure 26. The Hall plot for assessing the injection performance. 


\section{References}

Advanced Resources International: "Powder River Basin Coalbed Methane Development and Produced Water Management Study.” DOE/NETL-2003/1184, November 2002.

ALL Consulting and CH2M HILL: "Water Resources Technical Report," June 2001.

ALL Consulting: "Handbook on CBM Produced Water: Management and Beneficial Use Alternatives," Prepared for Ground Water Protection Research Foundation, U.S. Department of Energy, National Petroleum Technology Office, and Bureau of Land Management, July 2003.

Arthur, J.D., Langhus, B., Epperly, D., Bohm, B., Richmond, T. and Halvorson, J.: "Coal Bed Methane in the Powder River Basin of Montana," 2001.

Ayers, R. S. and D. W. Westcot: “Water Quality for Agriculture," FAO Irrigation and Drainage Paper 29, Rev. 1, U.N. Rome, 1985.

Ayers, W.B.: "Coalbed Gas Systems, Resources, and Production and A Review of Contrasting Cases from the san Juan and Powder River Basins.” AAPG Bulletin, v. 86, NO. 11, November 2002, pp. 1853-1890.

Bauder, J.W., and Pearson K.E.: "Justification for Numeric Standards of Salinity and Sodicity of Water To Be Considered For Beneficial Use For Irrigation," Department of Land Resources and Environmental Sciences, Montana State University - Bozeman, 2002.

Census 2000 PHC-T-18: “American Indian and Alaska Native Tribes in the Mountain Division," U.S. Census Bureau, Census 2000, special tabulation, September 2002.

Chaney, T.H., Kuhn, G., and Brooks, T.: "Northern Great Plains and Rocky Mountain Coal Provinces, Colorado and Utah." U.S. Geological Survey Water-Resources Investigation Open-File Report 85-479, Hydrology of area 58, 1987.

EPA report: "Draft Site Visit Report Coalbed Methane Operations, Gillette, WY." August 21, 2001. (http://www.epa.gov/region08/water/wastewater/npdeshome/cbm/cbm.html).

EPA presentation: "Economic Impact Analysis of Disposal Options for Produced Waters from Coaled Methane Operations in EPA Region 8," U.S. EPA, Office of Water, public meeting in Billings, MT, on September 25, 2001.

Hedges, R.B., Van Voast, W.A. and McDermott, J.J.: "Hydrology of the Youngs Creek-Squirrel Creek Headwaters Area, Southeastern Montana," Montana Bureau of Mines and Geology, 1976 (1998).

Hodgson, B.: "Profit By Reviewing Your Current Options and Costs for Treating CBM Produced Water," SRI Conference on CBM Water Management Strategies, Durango, CO., February, 2002.

International Association of Oil \& Gas Producers: "Guidelines for Produced Water Injection," Report No. 2.80/302, January 2000.

Mattax, C.C. and Dalton R.L.: "Reservoir Simulation," SPE monograph volume 13, 1990.

Mavor, M.J., Close, J.C., and McBane, R.A.: "Formation Evaluation of Exploration Coalbed-Methane Wells." SPE Formation Evaluation, December 1994, pp. 285-294.

Northern Cheyenne Tribe: "The Northern Cheyenne Tribe and Its Reservation," A report to the U.S. Bureau of Land Management and the State of Montana Department of Natural Resources and Conservation, April 2002.

Peaceman, D.W.: "Fundamentals of Numerical Reservior Simulation," Developments in Petroleum Science, 6, 1977.

Pritchett, R.W. and Bowen, M.J.: "Feasibility Study: Water Placement Related to Coalbed Methane Gas Production, Hanging Woman Basin Project.” Caribou Land \& Livestock Montana, LLC, December 2001.

Schneider, T.J.: "Coal Bed Methane Produced Water Reinjection,” May 2001.

Van Voast, W.A.: "Geochemical Signature of Formation Waters Associated with Coalbed Methane." AAPG Bulletin, v. 87, NO. 4, April 2003, pp. 667-676.

Warrence, N.J., Bauder, J.W., Pearson K.E.: "Salinity, Sodicity and Flooding Tolerance of Selected Plant Species of the Northern Cheyenne Reservation," Department of Land Resources and Environmental Sciences, Montana State University - Bozeman, 2001. 